\begin{tabular}{|c|c|c|c|}
\hline & $\begin{array}{l}\text { FATIH } \\
\text { SULTAN } \\
\text { MEHMET } \\
\text { VAKIF ÜNivERSiTESi }\end{array}$ & $\begin{array}{l}\text { FSM IImî Araştırmalar Insan ve Toplum Bilimleri Dergisi } \\
\text { FSM Scholarly Studies Journal of Humanities and Social Sciences } \\
\text { Sayı/Number } 17 \text { Yıl/Year } 2021 \text { Bahar/Spring } \\
\text { (c)2021 Fatih Sultan Mehmet Vakıf Üniversitesi }\end{array}$ & aris \\
\hline DOI: & & http://dergipark.org.tr/fsmia & http://dergi.fsm.edu.tr \\
\hline Araştır & lesi / Research Article & Geliş Tarihi / Received: 08.04.2021 Kabul Tarihi / Accepted: 31.05.2021 & FSMIAD, 2021; (17): 513-566 \\
\hline
\end{tabular}

\title{
A Coping Model for the Fear of COVID-19 in the Context of Coping and Psychological Resilience
}

Ayşe Gökmen*

Yasin Toprak**

Said Sami****

\begin{abstract}
The spread of COVID-19 reached pandemic rates in a few weeks. People have turned to coping and religious coping styles as a result of the psychological effects of COVID-19. In this context, this study's primary purpose is to reveal the relationship between fear of COVID-19, resilience, coping, and religious coping. In this article, where the quantitative research method was used, the relational screening design was adopted as the research design. Collected data were analyzed using correlation and structural equation modeling. According to the findings, women, single people, people from low-income fa-

Arş. Gör., Necmettin Erbakan Üniversitesi İlahiyat Fakültesi Felsefe ve Din Bilimleri Bölümü Din Psikolojisi Ana Bilim Dalı / Research Assistant, Necmettin Erbakan University Faculty of Theology Department of Philosophy \& Religious Sciences Psychology of Religion, Konya/ Türkiye, ayseemurat@gmail.com, orcid.org/0000-0002-0367-7688

** Uzman Psikolojik Danışman, Küçük Dikili İlkokulu / Psychological Counselor, M. A., Küçük Dikili Primary School, Adana/Türkiye, yasintoprakpdr@gmail.com, orcid.org/0000-00018130-5786

**** Arş. Gör., Gaziantep Üniversitesi İlahiyat Fakültesi Felsefe ve Din Bilimleri Bölümü Din Psikolojisi Ana Bilim Dalı / Research Assistant, Gaziantep University Faculty of Theology Department of Philosophy \& Religious Sciences Psychology of Religion, Gaziantep/Türkiye, saidsami2525@gmail.com, orcid.org/0000-0003-0007-0095
\end{abstract}


milies, and people with chronic conditions are more afraid of COVID-19. Also, resilience has been found to play a mediating role in the negative relationship between task-oriented coping and fear of COVID-19.

Keywords: COVID-19, coping, religious coping, resilience, fear, psychology.

\section{Başa Çıkma ve Psikolojik Dayanıklılık Bağlamında COVID-19 Korkusu İçin Bir Baş Etme Modeli}

\section{$\ddot{O} z$}

COVID-19'un yayılması birkaç hafta içinde salgın düzeyine ulaştı. İnsanlar COVID19`dan psikolojik olarak etkilendikleri için başa çıkma ve dini başa çıkma tarzlarına yöneldi. Bu bağlamda, bu çalışmanın temel amacı COVID-19 korkusu, psikolojik dayanıklılık, başa çıma ve dini başa çıkma arasındaki ilişkiyi ortaya koymaktır. Nicel araştırma yönteminin tercih edildiği bu makalede, araştırma deseni olarak ilişkisel tarama deseni benimsenmiştir. Toplanan veriler, korelasyon ve yapısal eşitlik modellemesi kullanılarak analiz edilmiştir. Bulgulara göre, kadınlar, bekarlar, düşük gelirli insanlar ve kronik rahatsızlığı olanlar COVID-19'dan daha çok korkmaktadır. Ayrıca, psikolojik dayanıklılı̆ı̆ı, çözüm odaklı başa çıkma ile COVID-19 korkusu arasındaki olumsuz ilişkide arabulucu bir rol oynadığı bulunmuştur.

Anahtar Kelimeler: COVID-19, başa çıkma, dini başa çıkma, dayanıklılık, korku. 


\section{Introduction}

As a result of globalization, pathological agents have spread rapidly and caused global pandemics (SARS, H1N1, EBOLA, ZIKA). ${ }^{1}$ A new infectious virus emerged in Wuhan, China, in December 2019. ${ }^{2}$ The spread of the virus, called COVID-19, has reached pandemic rates, affecting many countries within a few weeks. ${ }^{3}$ The World Health Organization ${ }^{4}$ declared the outbreak of COVID-2019 as an international public health emergency concern on 30 January 2020. In addition, strict precautions and the highly contagious nature of the virus have caused worldwide panic. ${ }^{5}$ However, scientists have been shown to understand pathophysiological mechanisms before psychological mechanisms to prevent and treat illness and detection vaccines. ${ }^{6}$ In such situations, the psychosocial dimension tends to be underestimated and neglected. ${ }^{7}$ Still, during epidemics, the number of people affected by the epidemic is more than the number of people affected by the infection. ${ }^{8}$ Therefore, to overcome COVID-19 completely, efforts to reduce the rate of transmission of the disease and psychological effects must be addressed. ${ }^{9}$

1 David M. Morens - Anthoney. S. Fauci, "Emerging Infectious Diseases: Threats to Human Health and Global Stability", PLoS Pathogens, vol. 9, no. 7, 2013, p. e1003467; Wei Zheng, "Mental Health and A Novel Coronavirus (2019-Ncov) in China", Journal of Affective Disorders, vol. 269, 2020, p. 201-202.

2 Jianyin Qiu et al., "A Nationwide Survey of Psychological Distress Among Chinese People in the COVID-19 Epidemic: Implications and Policy Recommendations", General psychiatry, vol. 33, no. 2, 2020, e100213corr1.

3 Andrea Remuzzi - Giuseppe Remuzzi, “COVID-19 and Italy: What Next?", The Lancet, vol. 395, 2020, p. 1225-1228; Jianyin Qiu et al., a.g.m., e100213corr1.

4 World Health Organization, Statement on The Second Meeting of The International Health Regulations (2005) Emergency Committee Regarding the Outbreak of Novel Coronavirus (2019-Ncov), 30 January 2020.

5 Jianyin Qiu et al., a.g.m., e100213corr1.

6 David M. Morens - Anthoney. S. Fauci, a.g.m., p. e1003467; Cuiyan Wang et al., a.g.m., p. 1729.

7 David M. Morens - Anthoney. S. Fauci, a.g.m., p. e1003467

8 Sara Reardon, "Ebola's Mental-Health Wounds Linger in Africa” Nature News, vol. 519, no. 7541, 2015, p. 13.

9 Daniel Kwasi Ahorsu et al., "The Fear of COVID-19 Scale: Development and Initial Validation”, International Journal of Mental Health and Addiction, 2020. 


\section{Fear, Anxiety and Other Psychological Effects}

The fear of the person who feels threatened is expected. ${ }^{10}$ While anxiety responds to a vague and unknown threat, fear responds to a threat that exists (such as COVID-19). Intense pressure and fear can manifest themselves in physical, psychological, emotional, and behavioral ways. ${ }^{11}$ Indeed, as individuals have begun to worry more about COVID-19 due to high infection rates and increased mortality, ${ }^{12}$ the psychological and behavioral responses to COVID-19 have become severe in the rising epidemic phase. ${ }^{13}$

Emotions such as fear, anxiety, anger, constriction, guilt, and rebellion are expected during a crisis. ${ }^{14}$ However, when the threat is uncertain and persistent, such as the coronavirus (COVID-19) pandemic, fear may become chronic, and this disproportionate fear may lead to the development of various psychiatric disorders. ${ }^{15}$ Psychosocial stress caused by social changes such as quarantine and social isolation measures due to viral infection also increases anxiety and stress levels, leading to increase in psychological disorders or an increase in symptoms of existing disorders. ${ }^{16}$ Indeed, strict quarantine measures in China have triggered

10 Robert Plutchik, "A General Psychoevolutionary Theory of Emotion” Emotion: Theory, Research, and Experience: Vol 1. Theories of Emotion, eds. Robert Plutchik - Hanry Kellerman, New York, Academic, 1980, p. 3-33.

11 Gordana Stankovska - Imran Memed1 - Dimitar Dimitrovski, "Coronavirus COVID-19 Disease, Mental Health, and Psychosocial Support”, Society Register, vol. 4, no. 2, 2020, p. 33-48.

12 Georgios Pappas et al., "Psychosocial Consequences of Infectious Diseases", Clinical Microbiology and Infection, vol. 15, no. 8, 2009, p. 743-747.

13 Mengcen Qian et al., "Psychological Responses, Behavioral Changes and Public Perceptions During the Early Phase of the COVID-19 Outbreak in China: A Population-Based Cross-Sectional Survey", medRxiv, 2020.

14 Felix Inchausti et al., "Psychological Intervention and COVID-19: What We Know So Far and What We Can Do", Journal of Contemporary Psychotherapy, 2020, p. 1-8.

15 Sung-Wan Kim - Kuan-Pin Su, "Using Psychoneuroimmunity Against COVID-19”, Brain, Behavior, and Immunity, 2020, p. 4-5; Gaetan Mertens et al., "Fear of The Coronavirus (COVID-19): Predictors in An Online Study Conducted in March 2020", Journal of Anxiety Disorders, 2020, 102258; Lisa M. Shin - Israel Liberzon, “The Neurocircuitry of Fear, Stress, and Anxiety Disorders", Neuropsychopharmacology, vol. 35, 2010, p. 169-91.

16 Li Duan - Gang Zhu, "Psychological Interventions For People Affected By The COVID-19 Epidemic", The Lancet Psychiatry, vol. 7, no. 4, 2020, p. 300-302; Hyun-Chung Kim et al., "Psychiatric Findings in Suspected and Confirmed Middle East Respiratory Syndrome Patients Quarantined in Hospital: A Retrospective Chart Analysis", Psychiatry investigation, vol. 15, no. 4, 2018, p. 355-360; Jun Shigemura et al., "Public Responses to The Novel 2019 Coronavirus (2019-Ncov) In Japan: Mental Health Consequences and Target Populations", Psychiatry and Clinical Neurosciences, 2020, p. 281-282; Chunfeng Xiao, “A Novel Approach 
psychological problems such as panic disorder, anxiety, and depression. ${ }^{17}$ When we look at similar outbreaks, more than 50 percent of SARS and MERS patients also experienced psychological problems. ${ }^{18}$

High emotional intensity motivates behavior ${ }^{19}$ In extreme situations such as pandemics, emotions such as anxiety, anger, fear of dying from illness, and despair can lead to suicidal behavior. ${ }^{20}$ The effect must be balanced. People have committed suicide, thinking that they are ill even though they are not infected with COVID-19 or because of fear of disease transmission and fear of stigma. ${ }^{21}$

\section{Coping}

Stress is a multivariate process that mediates coping behavior. ${ }^{22}$ According to Lazarus and Folkman, ${ }^{23}$ coping is a set of emotional and behavioral reactions to minimize problems by controlling internal and external requests and conflicts. ${ }^{24}$ For this reason, the individual experiencing stress first reviews the situation and evaluates whether he can cope with the stress. Then he decides on a coping strategy. These coping styles are named as task-oriented coping and emotion-oriented coping ${ }^{25}$

Task-oriented coping is a coping style that focuses on problem-solving and includes strategies such as information gathering and decision-making, including

of Consultation On 2019 Novel Coronavirus (COVID-19)-Related Psychological and Mental Problems: Structured Letter Therapy”, Psychiatry Investigation, vol. 17, no. 2, 2020, p. 175.

17 Jianyin Qiu et al., a.g.m., e100213corr1.

18 Hyun-Chung Kim et al., a.g.m., p. 355-360.

19 Charles. G. Morris, Psikolojiyi anlamak (Psikolojiye giriş), çev. H. Belgin Ayvaşık - Melike Sayıl, Ankara, Türk Psikologlar Derneği Yayınları, 2002, p. 432.

20 Mohammed A. Mamun - Mark D. Griffiths, "First COVID-19 Suicide Case in Bangladesh Due to Fear Of COVID-19 And Xenophobia: Possible Suicide Prevention Strategies", Asian Journal of Psychiatry, vol. 51, 2020, 102073; Nicola Montemurro, "The Emotional Impact of COVID-19: From Medical Staff to Common People", Brain, Behavior, and Immunity, 2020, p. 23-24.

21 Kapil Goyal et al., "Fear of COVID 2019: First Suicidal Case in India", Asian Journal of Psychiatry, vol. 49, 2020, e101989; Mohammed A. Mamun - Mark D. Griffiths, a.g.m., 102073.

22 Richard S. Lazarus, “Theory-based Stress Measurement”, Psychological Inquiry, vol 1, no. 1, 1990, p. 04.

23 Richard S. Lazarus - Susan Folkman, Stress, appraisal and coping, New York, Pringer, 1984, p. $141-151$.

24 Susan Folkman - Judith Tedlie Moskowitz, "Coping: Pitfalls and Promise", Annual Review of Psychology, vol. 55, 2004, p. 747.

25 Richard S. Lazarus - Susan Folkman, a.g.e., p. 141-151, 319. 
active effort. As a result of the individual taking responsibility, planning, and focusing on the problem, the stressful situation might be eliminated, or its effect might be reduced. On the other hand, emotion-oriented coping seeks to regulate negative emotions and adverse reactions that arise from stressful situations by avoiding, denying, focusing on emotions, and avoiding problems. ${ }^{26}$ The use of highly emotional-oriented coping styles is associated with higher post-traumatic stress symptoms and psychological distress, while task-oriented coping styles are associated with lower post-traumatic stress and psychological distress ${ }^{27}$. In addition to emotional and task-oriented coping, avoidant coping is considered the third basic coping style. Avoidant coping is an entirely passive strategy that includes cognitive and behavioral efforts such as underestimating, denying, or ignoring stressful situations ${ }^{28}$.

It is not just the individual's preferences that determine the style of coping. The characteristics of stressful situations are also fundamental. Suppose there is a situation that can be controlled at a high level. In that case, task-oriented coping styles are more effective, and emotion-oriented coping styles are more effective in situations that cannot be changed. ${ }^{29}$

Fears, difficulties, troubles are the driving forces that lead us to use coping styles. Instead of negative coping techniques such as avoiding, using coping styles that allow the individual to deal with the problem, facing the challanges, and adjusting emotional responses can transform a stressful situation into a structure that flourishes the person. ${ }^{30}$ In this study, coping styles are discussed to understand which coping styles individuals use during the difficult epidemic process that we are experiencing.

26 Richard S. Lazarus, "Coping Theory and Research: Past, Present, and Future”, Psychosomatic Medicine, vol. 55, 1993, p. 234-247; Richard S. Lazarus - Susan Folkman, a.g.e., p. 141-151; Shelly E. Taylor et al., Sosyal psikoloji, çev. Ali Dönmez. Ankara, İmge Kitabevi, 2010, 465.

27 Georges Brousse et al., "Management of Traumatic Events: Influence of Emotion-Centered Coping Strategies on The Occurrence of Dissociation and Post-Traumatic Stress Disorder", Neuropsychiatric Disease and Treatment, vol. 7, 2011, p. 127; Kimberly R. Schnider - Jon D. Elhai - Matt J. Gray, "Coping Style Use Predicts Posttraumatic Stress and Complicated Grief Symptom Severity Among College Students Reporting A Traumatic Loss", Journal of Counseling Psychology, vol. 54, no. 3, 2007, p. 344.

28 Charles J. Holahan et al., "Stress Generation, Avoidance Coping, and Depressive Symptoms: A 10-Year Model", Journal of Consulting and Clinical Psychology, vol. 73, no. 4, 2005, p. 658-666.

29 Richard S. Lazarus - Susan Folkman, a.g.e., p. 141-151; Shelly E. Taylor et al., a.g.e., p. 465.

30 Richard S. Lazarus - Susan Folkman, a.g.e., p. 141-151. 


\section{Religious Coping}

According to Pargament, the participation of religious beliefs and rituals in dealing with stressful and challenging situations is called religious coping. ${ }^{31} \mathrm{Re}-$ ligion has five primary goals to deal with problems; to gain meaning, to provide a sense of control and trust, to provide comfort, proximity, and social support, and to provide transformation. ${ }^{32}$ People may prefer coping with religion, especially when they experience events that they cannot control the painful moments. ${ }^{33}$ Religion offers a unity of meaning to individuals ${ }^{34}$ and enables us to see positive potentials in negative situations. Moreover, religious emphasis on human beings' limitations and human beings' inability has a protective function..$^{35}$

Individuals facing challenges use a variety of religious coping styles. These strategies, however, are not always positive. Therefore, spiritual coping techniques can be divided into positive and negative. ${ }^{36}$ Coping styles such as thinking well about what happened to you, seeking spiritual support when faced with troubling situations, worshiping, believing that even pain has a spiritual meaning, and cooperating with God in solve problems are defined as positive religious coping. ${ }^{37}$ On the other hand, some individuals believe that all these troubles as God's punishment due to spiritual disconnection with God's power and love God's. ${ }^{38}$ Moreover, poorly integrated religious coping strategies result in more anxiety and problem-solving difficulties. ${ }^{39}$ Thus, while positive religious coping styles benefit

31 Kenneth. I. Pargament, "The psychology of religion and coping: Theory, research, practice”, New York, The Guilford Press, 1997, p. 190-240.

32 Kenneth. I. Pargament, a.g.e., 1997, p. 190-240; Kenneth. I. Pargament - Herold G. Koenig Lisa Perez, "The Many Methods of Religious Coping: Development and Initial Validation of the RCOPE”, Journal of Clinical Psychology, vol. 56, no. 4, 2000, p. 519-543.

33 Kenneth. I. Pargament - Herold G. Koenig - Lisa Perez, a.g.m., p. 519-543.

34 Kenneth. I. Pargament - Curtis R. Brant, "Religion and coping" Handbook of religion and mental health, ed. Harold G. Koenig, San Diego, Academic Press, 1998, p. 111-128.

35 Kenneth. I. Pargament - Crystal L. Park, "Merely A Defense? The Variety of Religious Means and Ends", Journal of Social Issues, vol. 51, 1995, p. 13-32.

36 Kenneth I. Pargament et al., "Patterns of Positive and Negative Religious Coping with Major Life Stressors", Journal for the Scientific Study of Religion, 1998, p. 710-724.

37 Kenneth I. Pargament et al., a.g.m., 1998; Kenneth. I. Pargament - Herold G. Koenig - Lisa Perez, a.g.m., p. 519-543.

38 Kenneth. I. Pargament, a.g.e., 1997, p. 190-240; Kenneth I. Pargament et al., a.g.m., 1998; Kenneth. I. Pargament - Herold G. Koenig - Lisa Perez, a.g.m., p. 519-543.

39 Kenneth. I. Pargament et al., "Red Flags and Religious Coping: Identifying Some Religious Warning Signs Among People in Crisis", Journal of Clinical Psychology, vol. 59, no. 12, 2003, p. $1335-1348$. 
the individual more, negative religious coping styles can harm the individual. As a matter of fact, it has been determined that there is a negative relationship between COVID-19 anxiety and coping with COVID-19. ${ }^{40}$ Another study found that "religion" is the most commonly used coping strategy for the fear of contracting COVID-19. Indeed, positive religious coping, intrinsic religiosity and trust in God has been found strongly correlated with less stress, while negative religious coping and mistrust in God correlated with the inverse. ${ }^{41}$

\section{Resilience}

The concept of resilience is one of the principles of positive psychology that underpins human strengths such as optimism, forgiveness, psychological well-being, and responsibility. ${ }^{42}$ Resilience is the ability to manage an individual's cultural, psychological and social resources and thus overcome difficult situations. ${ }^{43}$ The individual's adaptation status to the problem at risk is evaluated in psychological resilience studies ${ }^{44}$ For resilience to occur, current or unpredictable conditions such as chronic poverty or traumatic incidents, must first be risk factors. ${ }^{45}$ Subsequently, individuals at risk should adapt to this situation and complete the process. ${ }^{46}$

Resilience is one of the most crucial protective factors facilitating coping with traumatic events ${ }^{47}$. Individuals with high resilience quickly regain their ba-

40 Abdullelah Alsolais et al., "Risk Perceptions, Fear, Depression, Anxiety, Stress and Coping Among Saudi Nursing Students During The COVID-19 Pandemic.", Journal of Mental Health, 12 May 2021, p. 1-8.

41 Steven Pirutinsky - Aaron D. Cherniak - David H. Rosmarin, "COVID-19, Mental Health, and Religious Coping Among American Orthodox Jews", Journal of Religion of the Health, vol. 59, 2020, p. 2288-2301.

42 Martin E. P. Seligman - Mihaly Csikzentmihalyi, "Positive Psychology: An Introduction", American Psychologist, vol. 55, 2000, p. 5-14.

43 Michael Ungar, "Resilience Across Cultures", British Journal of Social Work, vol. 38, no. 2, 2008, p. 218-235.

44 Özlem Kararırmak, "Psikolojik Sağlamlık, Risk Faktörleri ve Koruyucu Faktörler”, Türk Psikolojik Danışma ve Rehberlik Dergisi, cilt 3, sayı 26, 2006, s. 129-138.

45 Özlem Karaırmak - Rahşan Siviş-Çetinkaya, "Benlik Saygısının ve Denetim Odağının Psikolojik Sağlamlık Üzerine Etkisi: Duyguların Aracı Rolü”, Türk Psikolojik Danışma ve Rehberlik Dergisi, cilt 4, say1 35, 2011, s. 30-43; Ann. S. Masten - J. Douglas Coastworth, "The Development of Competence in Favorable and Unfavorable Environments: Lessons from Research on Successful Children", American Psychologist, vol. 53, no. 2, 1998, p. 205-220.

46 Ann. S. Masten - J. Douglas Coastworth, a.g.m., p. 205-220.

47 George A. Bonanno, "Loss, Trauma, and Human Resilience: Have We Underestimated the Human Capacity to Thrive After Extremely Aversive Events?", American Psychologist, vol. 59, 
lance in the face of stressful events and have the potential to progress despite difficulties. They are thus easily adapted to situations caused by traumatic events. ${ }^{48}$ Coping styles and resilience are effective at the level of adaptation to life, setting new goals, and achieving those goals. ${ }^{49}$

Incidents that negatively affect the mental health of individuals are increasing day by day. Earthquakes, terror, wars, fires, natural disasters are the cause of traumatic experiences. Therefore, essential concepts, such as coping and resilience, should be examined to restore normality and adaptation to life. In this context, this study will help identify the psychological effects of the virus in the context of the fear of COVID-19. In the literature, there is a negative relationship between fear of COVID-19 and resilience..$^{50}$ Resilience is a significant predictor of COVID-19 fear. ${ }^{51}$ Because resilience can play a protective role in reducing fear of COVID-19, increasing individuals' resilience levels and conducting resilience research are critical in dealing with the COVID-19 process.

\section{Purpose of the Study}

The current coronavirus pandemic (COVID-19) is a unique and rare condition that is effective worldwide. Since COVID-19 has affected almost every aspect of our lives, it has also affected people psychologically, from school to work. Research data are needed first to develop evidence-based strategies to reduce the negative psychological and psychiatric symptoms caused by the epidemic. ${ }^{52}$ Thus, this study focuses on the resilience and reveals a relationship between coping styles among individuals during the COVID-19 in Republic of Turkey. Furthermore, another aim was to develop a model for the relationship between these variables.

no. 1, 2004, p. 20-28; Michael Ungar, "Resilience, Trauma, Context, and Culture", Trauma, Violence, \& Abuse, vol. 14, no. 3, 2013, p. 255-266.

48 George A. Bonanno, a.g.m., p. 20-28.

49 Diana Spulber, "Coping and Resilience in Life-Long Learning and Ageing: New Challenges”, Geopolitical, Social Security and Freedom Journal, vol. 2, no. 1, 2019, p. 93-103.

50 Abdulkadir Haktanır - Tolga Seki - Bülent Dilmaç, "Adaptation and Evaluation of Turkish Version of The Fear of COVID-19 Scale", Death Studies, 29 May 2020, p. 1; Varol Tutal Mehmet Efe, "Bireylerin Psikolojik Sağlamlık ve Covid-19 Korkularının Çeşitli Değişkenlere Göre İncelenmesi”, Journal of International Social Research, vol. 13, no. 74, 2020, p. 322.

51 Yunus Altundağ, "Erken Dönem Covid-19 Pandemisinde Covid-19 Korkusu ve Psikolojik Dayanıkl111k", EKEV Akademi Dergisi, cilt 25, say1 85, 2021, s. 499-516.

52 Cuiyan Wang et al., "Immediate Psychological Responses and Associated Factors During the Initial Stage of the 2019 Coronavirus Disease (COVID-19) Epidemic Among the General Population in China", International Journal of Environmental Research and Public Health, vol. 17, no. 5, 2020, p. 1729. 


\section{Method}

\section{Study Design and Settings}

This study employed a quantitative research method, and the pattern of this study is the relational screening model included in the quantitative analyses. The relational screening model focuses on the existence, severity, and form (formulation or modeling) of the relationship between two or more variables. The technique used to examine the relationship varies depending on the purpose of the research analysis and data. ${ }^{53}$ Correlation analysis and structural equation modeling have been used in this study. Correlation is a method that shows the direction and strength/degree of the relationship between variables. ${ }^{54}$ Structural equation modeling is a multivariate method that tests the relationship sequences between testable and latent variables to the model..$^{55}$

\section{Sampling}

The research group consists of 823 people living in different parts of Turkey. Appropriate sampling was used to easily reach the sampling group. In this direction, the form containing the research questions was created using the Google Form, and an attempt was made to reach the sample via the internet.

Participants are between 16 and 65 years old. The participants were grouped as follows according to their stage of development: $5.3 \%$ in adolescents (16-18), $58.7 \%$ in young adults (19-29), 35.6\% in middle-aged (30-59), $0.4 \%$ in aged (60 and older). $37.5 \%$ of the participants are female, and $62.5 \%$ are male. $39.0 \%$ of the participants were married, $58.8 \%$ were single, and $2.2 \%$ were divorced. $1.5 \%$ of the participants have a primary school, $2.9 \%$ middle school, $13.2 \%$ high school, $9.6 \%$ college, $57.6 \%$ undergraduate, $15.2 \%$ graduate education level; $31.5 \%$ of them have low income, $35.6 \%$ of them have medium income, $32.9 \%$ of them

53 Recai Coşkun - Remzi Altunışık - Engin Yıldırım, Sosyal bilimlerde araştırma yöntemleri SPSS uygulamal, İstanbul, Sakarya Yayınc1lık 2017.

54 Yalçın Karagöz, SPSS 23 ve AMOS 23 Uygulamalı Istatistiksel Analizler, Ankara, Nobel Akademik Yayınc1lık, 2016, s. 693.

55 Yalçın Karagöz, a.g.e., s. 950; Tuba Şeker - Yavuz Tansoy Yıldırım, "Çalışanlarda Tükenmişlik ve Sanal Kaytarma Davranışları Arasındaki İlişkinin İncelenmesi: Enerji Sektöründe Bir Araştırma", Uygulamalı Ekonomi ve Sosyal Bilimler Dergisi, cilt 1, say1 2, 2019, 11 as cited in Barbara G. Tabachnick - Linda S. Fidell, "Principal Components and Factor Analysis", Using Multivariate Statistics, vol. 4, 2001, p. 582-633; Mehmet Dalkılıç - Veysel Temel, "Ergenlerde Öfke İfade Tarzları", V. International Congress on Natural and Health Sciences (ICNHS-2019), 2019, s. 141; Barbara G. Tabachnick - Linda S. Fidell, Çok Değişkenli Istatistiklerin Kullanımı, Ankara, Nobel Akademik Yayıncılık, 2015. 
have high-income level; $8 \%$ of them live in villages, $18.3 \%$ in towns, $22.7 \%$ in cities and $50.9 \%$ in big cities. While $11.2 \%$ of the participants have a chronic illness, $88.8 \%$ do not have a chronic disease.

\section{Research Instruments and Assessments}

\section{Coping Inventory for Stressful Situations-Short Form (CISS-21)}

A 21-question short form, SDBÇE, was adapted to Turkish by Boysan (2012) from the 48-question long-form developed by Endler and Parker. ${ }^{56}$ The scale is of the 5-Likert type and consists of three sub-dimensions. These are "Task-Oriented Coping," "Emotion-Based Coping," and "Avoidant Coping," respectively. Internal consistency values calculated for subscales were determined as Cronbach's alpha $=.72$ for task-oriented coping, Cronbach's alpha $=.77$ for emotional-oriented coping, and Cronbach's alpha $=.74$ for avoidant coping. Comparative Fit Index (CFI) equals or is over 0.90, Incremental Fit Index (IFI) equals or is over 0.90 , Non-Normed Fit Index (NNFI) equals or is over 0.90 . This three-factor structure has sufficient validity and reliability that can be used for research purposes. ${ }^{57}$

\section{Religious Coping Scale-RCOPE}

Religious Coping Scale-RCOPE was developed by Pargament, Smith, Koenig, and Perez. ${ }^{58}$ Ekşi, adapted the short form of the scale to Turkish and carried out the reliability studies. Reliability and item analysis were conducted in 1999-2000 with a group of 115 university students. The scale is of type 4-Likert and consists of 14 items and two sub-dimensions. These dimensions are divided into two, "Positive Religious Coping (PRC)" and "Negative Religious Coping (NRC)." Scale scores for the measurements are calculated separately, and the total score for the scale is not obtained. It was found that the PRC subscale explained 21.48 percent of the variance and that the NRC subscale explained 16.11 percent of the variance. The Cronbach alpha coefficient, which is one of the critical indicators of internal consistency, was calculated at 0.64 for the whole scale, while at 0.64 for the PRC and 0.63 for the NRC. Also, all items were found to have a $\mathrm{p}<0.1$ significance level. ${ }^{59}$ Cronbach's Alpa value was found to be 0.77

56 Normen S. Endler - James D. A. Parker, Coping Inventory for Stressful Situations (CISS): Manual, Toronto, Multi-Health Systems Incorporated, 1990.

57 Murat Boysan, "Validity of the Coping Inventory for Stressful Situations-Short Form (CISS21) in A Non-Clinical Turkish Sample", Düşünen Adam-The Journal of Psychiatry and Neurological Sciences, cilt 25, say1 2, 2012, s. 101-107.

58 Kenneth I. Pargament - Bruce W. Smith - Herold. G. Koenig - Lisa Perez, a.g.m., 1998.

59 Halil Ekşi, "Başaçıkma, Dinî Başaçıkma ve Ruh Sağlı̆̆ı Arasındaki Ilişki Üzerine Bir Araştır- 
(overall reliability score) after an internal consistency analysis was performed to test the scale's reliability in a study conducted in Turkey. ${ }^{60}$ It was found to be 0.56 in another study. ${ }^{61}$

\section{The Brief Resilience Scale (BRS)}

The Brief Resilience Scale (BRS) was developed to measure the levels of resilience of individuals. Doğan made one of the Turkish scale adaptations. The scale consists of six items and has a 5-point Likert structure. The adaptation process of the scale was carried out on 295 university students. Analysis of the exploratory factor was conducted to determine the construct validity of the scale. A one-factor structure that explains $54 \%$ of the total variance was obtained from the factor analysis. The internal consistency coefficient for BRS was determined to be .83 . BRS, DFA result fit goodness indices $\mathrm{x} 2 / \mathrm{df}(12.86 / 7)=1.83, \mathrm{NFI}=$ $0.99, \mathrm{NNFI}=0.99, \mathrm{CFI}=0.99, \mathrm{IFI}=0.99 \mathrm{RFI}=0.97, \mathrm{GFI}=0.99, \mathrm{AGFI}=0.96$, RMSEA $=0.05$, SRMR $=0.03$. In the context of the criterion-related validity, positive correlations were found between BRS and Oxford Happiness Questionnaire, Ego Strength Scale, and Connor Davidson Resilience Scale. It is concluded that the BRS is a valid and reliable instrument. ${ }^{62}$ The Cronbach Alpha coefficient was calculated to be $0.86^{63}$ and $0.82^{64}$ in other studies.

\section{The Fear of COVID-19 Scale}

The Fear of COVID-19 Scale was developed by Ahorsu et al. ${ }^{65}$ and one of the Turkish adaptations was made by Bakioğlu, Korkmaz and Ercan. The scale is uni-dimensional, consists of 7 items, and has a 5-point Likert structure. Confir-

ma: Eğitim, İlâhiyat ve Mühendislik Fakültesi Öğrencilerinin Karşılaştırılması.”, (Yayımlanmamış Doktora Tezi), Uludağ Üniversitesi, Bursa, 2001.

60 Veysel Uysal - Ayşe Kaya Göktepe - Sema Karagöz - Melike İlerisoy, "Dinî Başa Çıkma ile Umut, Hayat Memnuniyeti ve Psikolojik Sağlamlık Arasındaki Etkileşim Üzerine Bir Araştırma”, Marmara Üniversitesi İlâhiyat Fakültesi Dergisi, cilt 52, say1 52, 2017, s. 145.

61 Ayşe Şentepe, "Yaşlılık Döneminde Dini Başaçıkma", Insan ve Toplum Bilimleri Araştırmaları Dergisi, cilt 4, say1 1, 2015, s. 191.

62 Tayfun Doğan, “Kısa Psikolojik Sağlamlık Ölçeği’nin Türkçe Uyarlaması: Geçerlik ve Güvenirlik Çalışması”, The Journal of Happiness \& Well-Being, cilt 3, sayı 1, 2015, s. 93-102.

63 Mehmet Akif Karaman - Ajitha Chandrika Kumaran - Abdulkadir Haktanir - Stephen Lenz, "Predictors of Counselor-in-Training Students' General Self-Efficacy", Akdeniz Eğitim Araştırmalart Dergisi, cilt 12, say1 25, s. 140, (doi:10.29329/mjer.2018.153.8.)

64 Cemile Çetin - Özlem Anuk, "COVID-19 Pandemi Sürecinde Yalnızlık ve Psikolojik Dayanıklılık: Bir Kamu Üniversitesi Öğrencileri Örneklemi”, Avrasya Sosyal ve Ekonomi Araştırmaları Dergisi, cilt 7, say1 5, 2020, s. 170-189.

65 Daniel Kwasi Ahorsu et al., a.g.m. 
matory factor analysis (CFA) was conducted to adapt the scale to Turkish. Item analysis was carried out, and the Cronbach alpha internal consistency coefficient was calculated. As a result of the CFA, goodness of fit indices were found to be at a good level $(\chi 2=22.08, \mathrm{sd}=9, \mathrm{p}<.001 ; \chi 2 / \mathrm{sd}=2.45 ; \mathrm{RMSEA}=.03$; CFI $=.99 ; \mathrm{IFI}=.99 ; \mathrm{GFI}=.99 ; \mathrm{AGFI}=.99 ; \mathrm{NFI}=.99 ; \mathrm{TLI}=.99 ; \mathrm{RFI}=.99 ; \mathrm{SRMR}$ $=.014)$. The factor load values of the items were determined to vary between .73 and .82. The one-dimensional and 7-item scale's eigenvalue was 4.12, and the total explained variance was $58.86 \%$. The corrected item-total correlations of the scale items range from .62 to .72, and Cronbach's Alpha internal consistency coefficient was determined as $.88 .{ }^{66}$ The Cronbach Alpha factor was determined to be 0.86 in other studies conducted in Turkey. ${ }^{67}$

\section{The Personal Information Form}

Researchers prepared the personal information form used in the study to determine participants' status according to different variables. The personal information form consists of a total of 7 items, including questions on educational status, place of residence, gender, age, marital status, monthly income level, and chronic illness.

\section{Data Collection Procedure}

Participants were reached using the snowball method via the Google research form. The research link shared by the various social media accounts was requested to be filled in by the people in this group and delivered to others around them. Volunteer participation was emphasized at the beginning of the study, and information on the research was provided. In the study, 873 people have been reached. However, due to extreme missing data, 50 cases were not included in the analysis. A total of 823 data were analyzed for the research.

\section{Data Analyses}

IBM SPSS 22 and AMOS 22 programs have been used to process and interpret the participants' data. First, the raw data collected was transferred to these programs and prepared for analysis, and analysis processes were carried out.

66 Fuad Bakioğlu - Ozan Korkmaz - Hülya Ercan, "Fear of COVID-19 and Positivity: Mediating Role of Intolerance of Uncertainty, Depression, Anxiety, and Stress", International Journal of Mental Health and Addiction, Mayis 2020.

67 Abdulkadir Haktanır - Tolga Seki - Bülent Dilmaç, a.g.m., p. 4; Nefise Ladikli - Erdi Bahadır - Fatıma Nurefşan Yumuşak - Hüdanur Akkuzu - Gülşen Karaman - Zeynep Türkkan, "Kovid-19 Korkusu Ölçeği’nin Türkçe Güvenirlik ve Geçerlik Çalışması”, International Journal of Social Science, cilt 3, say1 2, 2020, p. 77. 
Correlation analysis and structural equation model were used to analyze the relationship between coping with stressful situations, resilience, religious coping, and COVID-19 fear. Erroneous data was detected and corrected before analysis. Before the analysis, the suitability of the data for the factor analysis was checked, the skewness and the kurtosis coefficient were examined to measure the normality of the data. The reliability analysis of the scales was examined. Before analyzing the research model, a correlation analysis was conducted to determine the relationship between variables. The values of $\mathrm{x} 2$ / df, NFI, TLI and RMR, GFI, IFI, CFI, RMSEA, SRMR, and AGFI were examined to determine the research model's accordance to determine the construct validity of the scales. Following these preliminary analyzes, the structural equation model was used for the relationship sequences and predictors between the study variables. Moreover, the variables' values are shown in the tables in numbers and percentages using the frequency distribution and the descriptive statistics. Furthermore, the arithmetic mean values of the scale scores were examined according to variables such as gender, marital status, income status, or chronic disease.

\section{Results}

\section{Findings of Preliminary Analysis}

The analysis results concerning the suitability, normality, and reliability of the data for analysis are included in this section.

Table 1. The assessment into the suitability of data for analysis

\begin{tabular}{lllll}
\hline Scale & Subscale & KMO & Chi-Square & Sig. \\
\hline Coping with & Task-Oriented Coping & .89 & 1991.10 & .000 \\
Stressful Situations & Emotion-Oriented Coping & .87 & 1897.56 & .000 \\
& Avoidant Coping & .76 & 1587.82 & .000 \\
\multirow{2}{*}{ Religious Coping } & Positive Coping & .89 & 233.55 & .000 \\
& Negative Coping & .68 & 793.94 & .000 \\
Resilience & Resilience & .87 & 1923.29 & .000 \\
Fear of COVID-19 & Fear of COVID-19 & .87 & 235.45 & .000 \\
\hline
\end{tabular}

$* p<.05$.

The suitability of the data for analysis can be examined with Kaiser-Meyer-Olkin (KMO) and Bartlett tests. ${ }^{68}$ High correlations between variables

68 Yalçın Karagöz. a.g.e., s. 884. 
should be established to be appropriate for factor analysis since $\mathrm{p}($ sig.) $<0.5$, the result of the Barlet test was significant. Therefore, high correlations between variables and data indicate multiple normal distributions. The KMO value provides information on the adequacy of the sample size ${ }^{69}$ and is expected to be greater than $.60 .{ }^{70}$ The fact that the KMO is greater than. 60 and the Barlett test is positive indicates that the sample size is adequate and the scale item correlations are high. The results in Table 1 show that the data are suitable for factor analysis.

Table 2. Skewness and kurtosis coefficients as regards the normality of the data

\begin{tabular}{lcccc}
\hline & Skewness-S & Kurtosis-K & Standard Deviation & Cronbach Alpha \\
\hline EOC & .445 & -.211 & 5.9 & .83 \\
TOC & -.399 & -.101 & 5.2 & .85 \\
AOC & .077 & -.503 & 5.5 & .74 \\
R & -.174 & -.76 & .79 & .88 \\
PRC & -.797 & -.027 & .69 & .85 \\
NRC & .858 & .748 & .42 & .65 \\
C-19 & .665 & -.033 & .83 & .85 \\
\hline
\end{tabular}

Note: TOC $=$ Task-Oriented Coping, EOC: Emotion Oriented Coping, AOC: Avoidant Oriented Coping PR: Resilience, PRC: Positive Religious Coping, NRC: Negative Religious Coping, C-19: Fear of COVID-19.

Normal data distribution is a prerequisite for almost all parametric tests. ${ }^{71}$ The skewness and kurtosis coefficients should be between +1.5 and- 1.5 to accept that the data are typically distributed. ${ }^{72}$ Based on the results in Table 2 , it can be said that the data shows a normal distribution. A reliability value of . $60 \leq \alpha<.80$ indicates that the scale is reliable, and $.80 \leq \mathrm{a}<1.00$ suggests that it is highly reliable. ${ }^{73}$ Studies that do not use random sampling may raise doubts about their

69 Yalçın Karagöz, a.g.e., s. 884.

70 Şener Büyüköztürk, Sosyal Bilimler İçin Veri Analizi El Kitabı, Ankara, Pegem Akademi, 2012, s. 126.

71 Recai Coşkun - Remzi Altunışık - Engin Yıldırım, a.g.e., 2017.

72 Tuba Şeker - Yavuz Tansoy, a.g.m., 2019, s. 11, as cited in Barbara G. Tabachnick, - S. Fidell Linda, "Principal Components and Factor Analysis", Using Multivariate Statistics, vol. 4, 2001, p. 582-633.

73 Yalçın Karagöz. a.g.e., s. 884. 
validity and reliability. ${ }^{74}$ It is vital at this point that the reliability values are at an acceptable level. Information on the validity of this study is given in the Model Study section of Table 9 .

\section{Findings on Categorical Variables}

Since the appropriate sampling method, a non-probability sampling method, was used in this study, the categorical variables' scale scores were interpreted based on the averages. Average scores for categorical variables such as gender, chronic illness, marital status, age, and income status are shown in Tables 3, 4, 5 , 6,7 , respectively.

Table 3. Average scores of variables for the status of gender

\begin{tabular}{lllll}
\hline Variables & Gender & $\boldsymbol{N}$ & $\bar{X}$ & \multicolumn{1}{c}{$\boldsymbol{S S}$} \\
\hline Resilience & Male & 309 & 3.54 & .69 \\
\multirow{2}{*}{ Fear of COVID-19 } & Female & 514 & 3.18 & .83 \\
\cline { 2 - 5 } Positive Religious Coping & Male & 309 & 1.97 & .72 \\
& Female & 514 & 2.43 & .85 \\
\cline { 2 - 5 } Negative Religious Coping & Male & 309 & 3.28 & .58 \\
\multirow{2}{*}{ Task-Oriented Coping } & Female & 514 & 3.26 & .57 \\
\cline { 2 - 5 } & Male & 309 & 1.62 & .41 \\
Emotion-Oriented Coping & Female & 514 & 1.54 & .42 \\
\cline { 2 - 5 } & Male & 309 & 25.99 & 5.22 \\
Avoidant Coping & Female & 514 & 25.21 & 5.30 \\
\cline { 2 - 5 } & Male & 309 & 18.72 & 5.07 \\
& Female & 514 & 20.77 & 6.33 \\
\cline { 2 - 5 } & Male & 309 & 19.42 & 5.24 \\
\hline
\end{tabular}

There is no considerable change for gender in Table 3 when considering the positive religious coping mean scores. A remarkable increase was observed in the mean scores of resilience, negative religious coping, and task-oriented coping in favor of men. Mean scores of fear of COVID-19, emotion-oriented coping, and avoidant coping were higher for women.

According to Table 4, the average score of patients with chronic illness fear of COVID-19 shows a remarkable increase. Again, according to the table, there is no noticeable change in the presence or absence of chronic disease in other variables.

74 Recai Coşkun - Remzi Altunışık - Engin Yıldırım, a.g.e., 2017. 
Table 4. Average scores of variables for the illness status

\begin{tabular}{lllll}
\hline Variables & Illness & $\boldsymbol{n}$ & $\bar{X}$ & $\boldsymbol{S S}$ \\
\hline Resilience & Yes & 92 & 3.17 & .90 \\
\multirow{2}{*}{ Fear of COVID-19 } & No & 731 & 3.34 & .78 \\
\cline { 2 - 5 } Positive Religious Coping & Yes & 92 & 2.43 & .91 \\
& No & 731 & 2.24 & .82 \\
\cline { 2 - 5 } Negative Religious Coping & Yes & 92 & 3.20 & .61 \\
\multirow{3}{*}{ Task-Oriented Coping } & No & 731 & 3.28 & .57 \\
\cline { 2 - 5 } & Yes & 92 & 1.55 & .46 \\
Emotion-Oriented Coping & No & 731 & 1.58 & .41 \\
\cline { 2 - 5 } & Yes & 92 & 24.82 & 5.72 \\
Avoidant Coping & No & 731 & 25.60 & 5.22 \\
\cline { 2 - 5 } & Yes & 92 & 21.14 & 6.09 \\
& No & 731 & 19.86 & 5.94 \\
\cline { 2 - 5 } & Yes & 92 & 19.91 & 5.49 \\
\hline
\end{tabular}

Table 5. Average score results of variables for age group differences

\begin{tabular}{lllll}
\hline Variables & Age & $\boldsymbol{n}$ & $\bar{X}$ & $\boldsymbol{S S}$ \\
\hline Resilience & Under 30 & 527 & 3.20 & .81 \\
Fear of COVID-19 & Over 30 & 296 & 3.52 & .74 \\
\cline { 2 - 5 } & Under 30 & 527 & 2.27 & .81 \\
Positive Religious Coping & Over 30 & 296 & 2.23 & .88 \\
\cline { 2 - 5 } & Under 30 & 527 & 3.19 & .58 \\
Negative Religious Coping & Over 30 & 296 & 3.39 & .54 \\
\cline { 2 - 5 } & Under 30 & 527 & 1.60 & .43 \\
Task-Oriented Coping & Over 30 & 296 & 1.52 & .40 \\
\cline { 2 - 5 } & Under 30 & 527 & 25.23 & 5.39 \\
Emotion-Oriented Coping & Over 30 & 296 & 25.99 & 5.06 \\
\cline { 2 - 5 } & Under 30 & 527 & 20.40 & 6.04 \\
Avoidant Coping & Over 30 & 296 & 19.28 & 5.77 \\
\cline { 2 - 5 } & Under 30 & 527 & 20.71 & 5.74 \\
\hline
\end{tabular}


Resilience, positive religious coping, and task-oriented coping levels of individuals over the age of 30 are higher than the average score of individuals under the age of 30 (Table 5). Individuals under the age of 30 have remarkably high levels of negative religious coping, emotional coping, and avoidant coping compared to individuals over 30 . There was no significant change in fear of COVID-19 scores in terms of age.

In this study, the mean scores of divorced individuals in terms of resilience and task-oriented coping, the negative coping level and the preventative coping level of singles, and the positive coping level of married couples are noticable higher. However, no significant change in marital status has been observed for other variables (Table 6).

Table 6. Average score results of variables for marital status differences

\begin{tabular}{|c|c|c|c|c|}
\hline Variables & $\begin{array}{l}\text { Marital } \\
\text { Status }\end{array}$ & $n$ & $\bar{X}$ & $S S$ \\
\hline \multirow[t]{3}{*}{ Resilience } & Married & 321 & 3.50 & .74 \\
\hline & Single & 483 & 3.18 & .81 \\
\hline & Divorced & 18 & 3.82 & .72 \\
\hline \multirow[t]{3}{*}{ Fear of COVID-19 } & Married & 321 & 2.23 & .86 \\
\hline & Single & 483 & 2.28 & .82 \\
\hline & Divorced & 18 & 2.13 & .72 \\
\hline \multirow[t]{3}{*}{ Positive Religious Coping } & Married & 321 & 3.38 & .55 \\
\hline & Single & 483 & 3.19 & .57 \\
\hline & Divorced & 18 & 3.28 & .76 \\
\hline \multirow[t]{3}{*}{ Negative Religious Coping } & Married & 321 & 1.54 & .21 \\
\hline & Single & 483 & 1.60 & .43 \\
\hline & Divorced & 18 & 1.36 & .29 \\
\hline \multirow[t]{3}{*}{ Task-Oriented Coping } & Married & 321 & 25.88 & 5.15 \\
\hline & Single & 483 & 25.18 & 5.36 \\
\hline & Divorced & 18 & 27.72 & 4.76 \\
\hline \multirow[t]{3}{*}{ Emotion-Oriented Coping } & Married & 321 & 19.49 & 5.80 \\
\hline & Single & 483 & 20.37 & 6.10 \\
\hline & Divorced & 18 & 20.00 & 4.85 \\
\hline \multirow[t]{3}{*}{ Avoidant Coping } & Married & 321 & 19.38 & 5.21 \\
\hline & Single & 483 & 20.75 & 5.76 \\
\hline & Divorced & 18 & 20.11 & 5.31 \\
\hline
\end{tabular}


As shown in Table 7, the average resilience scores of those with high-income status are remarkably higher than other income levels. Additionally, low-income participants were found to have higher mean scores for fear of COVID-19 than different income levels. Individuals with high incomes have been found to have higher negative religious coping scores. On the other hand, the mean scores of the task-oriented coping group of those with high-income status have been remarkably higher than different income levels. Emotion-oriented coping scores of those with low income are significantly higher than other levels of income. There was, however, no significant difference between positive religious coping and avoidant coping and income levels.

Table 7. Average score results for income level differences for variables

\begin{tabular}{|c|c|c|c|c|}
\hline Variables & Income & $n$ & $\bar{X}$ & $S$ \\
\hline \multirow[t]{3}{*}{ Resilience } & Low & 259 & 3.20 & .82 \\
\hline & Middle & 293 & 3.27 & .81 \\
\hline & High & 271 & 3.48 & .73 \\
\hline \multirow[t]{3}{*}{ Fear of COVID-19 } & Low & 259 & 2.33 & .89 \\
\hline & Middle & 293 & 2.29 & .82 \\
\hline & High & 271 & 2.15 & .78 \\
\hline \multirow[t]{3}{*}{ Positive Religious Coping } & Low & 259 & 3.29 & .55 \\
\hline & Middle & 293 & 3.28 & .56 \\
\hline & High & 271 & 3.23 & .62 \\
\hline \multirow[t]{3}{*}{ Negative Religious Coping } & Low & 259 & 1.63 & .58 \\
\hline & Middle & 293 & 1.58 & .46 \\
\hline & High & 271 & 1.52 & .39 \\
\hline \multirow[t]{3}{*}{ Task-Oriented Coping } & Low & 259 & 24.87 & 5.73 \\
\hline & Middle & 293 & 25.53 & 5.10 \\
\hline & High & 271 & 26.09 & 4.96 \\
\hline \multirow[t]{3}{*}{ Emotion-Oriented Coping } & Low & 259 & 20.71 & 6.13 \\
\hline & Middle & 293 & 20.13 & 5.97 \\
\hline & High & 271 & 19.19 & 5.73 \\
\hline \multirow[t]{3}{*}{ Avoidant Coping } & Low & 259 & 20.32 & 5.90 \\
\hline & Middle & 293 & 20.54 & 5.32 \\
\hline & High & 271 & 19.61 & 5.50 \\
\hline
\end{tabular}




\section{Findings on The Relationship Between Variables}

The findings on the relationship between fear of COVID-19, resilience, religious coping, and coping with stress were analyzed with correlation analysis.

As shown in Table 8, there is a significant negative relationship between fear of COVID-19 and resilience $(r=-299)$, task-oriented coping $(r=-.11)$, and emotional- oriented coping $(\mathrm{r}=-.28)$. A significant positive relationship was found between the fear of Covid-19 and avoidant coping $(r=.106)$. While there was a significant positive $(r=.096)$ correlation between fear of COVID-19 and negative religious coping, there was no significant relationship with positive religious coping.

In addition, a significant negative correlation was found between resilience and negative religious coping $(\mathrm{r}=-.239)$ and emotional-oriented coping $(\mathrm{r}=$ -.556). There was a significant positive correlation between resilience and positive religious coping $(\mathrm{r}=.172)$ and task-oriented coping $(\mathrm{r}=487)$. However, no meaningful relationship was found between resilience and avoidant coping.

It was found that there was a positive relationship between task-oriented coping and positive religious coping $(r=.296)$ and a negatively significant relationship with negative religious coping $(\mathrm{r}=-.133)$. While a significant negative $(\mathrm{r}$ $=-.005$ ) relationship was found between emotional-oriented coping and positive religious coping, a positive $(\mathrm{r}=.325)$ significant association was found between emotional-oriented coping and negative religious coping.

Table 8. Correlation analysis results for variables

\begin{tabular}{llllllll}
\hline & C-19 & PR & PRC & NRC & TOC & EOC & AOC \\
\hline C-19 & 1 & & & & & & \\
PR & $-.299^{*}$ & 1 & & & & & \\
PRC & -.015 & $.172^{*}$ & 1 & & & & \\
NRC & $.096^{*}$ & $-.239^{*}$ & $.139^{*}$ & 1 & & & \\
TOC & $-.111^{*}$ & $.487^{*}$ & $.296^{*}$ & $-.133^{*}$ & 1 & & \\
EOC & $-.276^{*}$ & $-.556^{*}$ & -.005 & $.325^{*}$ & $-.218^{*}$ & 1 & \\
AOC & $.106^{*}$ & .037 & .067 & .030 & $.195^{*}$ & $.126^{*}$ & 1 \\
\hline
\end{tabular}

Note: $\mathrm{TOC}=$ Task-Oriented Coping, EOC: Emotion Oriented Coping, AOC: Avoidant Oriented Coping PR: Resilience, PRC: Positive Religious Coping, NRC: Negative Religious Coping, C-19: Fear of COVID-19. $\left({ }^{*} p<.05\right)$ 


\section{Results of The Structural Equation Modeling}

The goodness of the fit indexes for the model established and the scales used are shown in Table 9.

Table 9. The goodness of fit indices of models and scales

\begin{tabular}{|c|c|c|c|c|c|c|c|}
\hline $\begin{array}{l}\text { The } \\
\text { goodness } \\
\text { of the fit } \\
\text { indexes }\end{array}$ & $\begin{array}{l}\text { Last } \\
\text { Model }\end{array}$ & C-19 & RCOPE & BRS & CISS-21 & Good fit ${ }^{1}$ & Acceptable fit ${ }^{1}$ \\
\hline$\chi^{2}$ & 908.16 & 38.986 & 325.671 & 30.97 & 662.58 & $0 \leq \chi^{2} \leq 2 \mathrm{sd}$ & $2 \mathrm{sd} \leq \chi^{2} \leq 3 \mathrm{sd}$ \\
\hline $\mathrm{Sd}$ & 320 & 10 & 70 & 8 & 179 & & \\
\hline$P$ & .000 & .000 & .000 & .000 & .000 & & \\
\hline$\chi^{2} / \mathrm{sd}$ & 2.84 & 3.89 & 4.65 & 3.87 & 3.70 & $\begin{array}{l}0 \leq \chi^{2} / \mathrm{sd} \\
\leq 3\end{array}$ & $3 \leq \chi^{2} / \mathrm{sd} \leq 5$ \\
\hline GFI & .92 & .99 & .95 & .99 & .93 & $\geq .90$ & $\geq .85$ \\
\hline AGFI & .90 & .96 & .92 & .97 & .91 & $\geq .90$ & $\geq .85$ \\
\hline RMR & .05 & .03 & .04 & .03 & .10 & $\leq .05$ & $\leq .08$ \\
\hline TLI & .93 & .97 & .90 & .98 & .91 & $\geq .95$ & $\geq .90$ \\
\hline CFI & .94 & .99 & .92 & .99 & .92 & $\geq .97$ & $\geq .95$ \\
\hline NFI & .90 & .98 & .91 & .98 & .89 & $\geq .95$ & $\geq .90$ \\
\hline IFI & .94 & .99 & .92 & .99 & .92 & $\geq .95$ & $\geq .90$ \\
\hline SRMR & .04 & .03 & .08 & .02 & .08 & $\leq .05$ & $\leq .08$ \\
\hline RMSEA & .05 & .06 & .07 & .06 & .06 & $\leq .05$ & $\leq .08$ \\
\hline
\end{tabular}

Note: CISS-21: Coping Inventory for Stressful Situations-Short Form, RCOPE: Religious Coping Scale, BRS: The Brief Resilience Scale, C-19: The Fear of COVID-19 Scale.

According to the model's fitness indices shown in Table 9, the model is within acceptable fitness limits and is valid. ${ }^{75}$ Also, the scales used in the study are shown to be valid scales.

\section{Model Test Results}

The observed variables for fear of COVID-19 scale were created in the first model presented in Figure 1 by considering the total scores for other scales and the multiple correlations between these variables. 


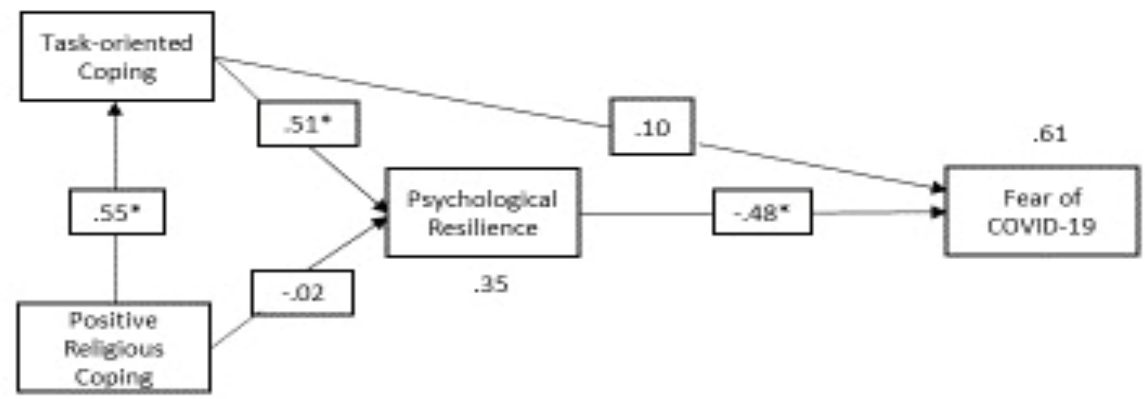

Figure 1. Path analysis and standardized regression coefficients of the first model $(* p<.001)$

Figure 1 shows the values of the regression coefficients and the significance of the hypotheses test results. The path between positive religious coping and resilience, and the path between task-oriented coping and COVID-19 fear, did not seem meaningful. For this reason, these pathways were excluded one by one and not added to the analysis model. ${ }^{76}$ Figure 2 shows the analysis of the path and the standardized regression coefficients for the final model.

.52

35

.62

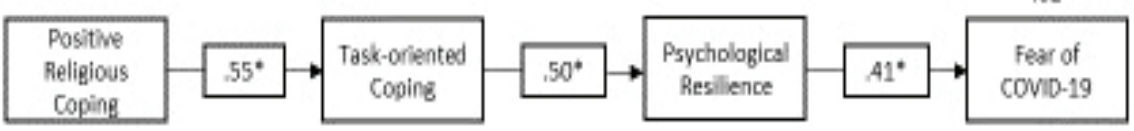

Figure 2. Path analysis and standardized regression coefficient for the final model $(* \mathrm{p}<.001)$

Table 10 includes values for regression coefficients and significance levels for model test results.

Figure 2, the path analysis and the standard regression coefficients for the final model, Table 10 shows the standardized regression coefficients and significance levels. The model-created predictor explains 52 percent of task-oriented coping, 35 percent of resilience, and 62 percent of COVID-19 fear.

Positive religious coping is a significant predictor of task-oriented coping $(t=7.87 ; p<.001, \beta=.55)$.

Task-oriented coping is a significant predictor of resilience $(t=11.67 ; p<.001$, $\beta=.51)$.

Resilience is a significant predictor of fear of COVID-19 7.74; $p<.001, \beta=-.48$ ).

76 Yalçın Karagözi a.g.e., s. 884. 
There is a positive relationship between positive religious coping and resilience. ${ }^{77}$ Indeed, religious coping not only contributes to resilience but also plays a unique role in this relationship. ${ }^{78}$ There is also a positive relationship between positive religious coping styles and task-oriented coping. ${ }^{79}$ In this regard, positive religious coping is thought to increase resilience by directing the individual to be task-oriented.

Table 10. Standardized coefficients of regression and significance level

\begin{tabular}{lllllll}
\hline Path & Un. Std. Est. & Std. Est. & $\mathbf{R}^{2}$ & Std. H. & $\boldsymbol{t}$ & $\boldsymbol{p}$ \\
\hline TOC $\leftarrow$ PRC & .34 & .55 & & .070 & 7.87 & $* * * 2$ \\
R. $\leftarrow$ TOC & .55 & .50 & & .041 & 12.19 & $* * * 2$ \\
C-19 $\leftarrow$ R. & -.35 & -.41 & & .049 & -8.36 & $* * * 2$ \\
TOC & & & .52 & & & \\
R. & & & .35 & & & \\
C-19 & & & .62 & & & \\
\hline
\end{tabular}

${ }^{1} p<.01,{ }^{2} p<.001$, Note: TOC $=$ Task-Oriented Coping, R: Resilience, PRC: Positive Religious Coping, C-19: Fear of COVID-19.

\section{Results of Mediation Testing}

The model shown in Figure 2 shows that task-oriented coping mediates the relation between positive religious coping and resilience. Besides, resilience appears to mediate the relation between task-oriented coping and the fear of COVID-19. However, because there was no significant relationship found in this study between fear of COVID-19 and positive religious coping, only the second relationship is explained here.

The mediating role of resilience in the relation between task-oriented coping and COVID-19 fear has been explored. The goodness of the fitness values of the model established for analysis was found to $b e x^{2} / d f=2.812$ and $p=000$. According to these values, the model is seen to be meaningful. The fit index values are

77 Laura McIntire - Renae Duncan, “Associations Among Religious Coping, Daily Hassles, and Resilience", Archive for the Psychology of Religion, vol. 35, no. 1, 2013, p. 101-117.

78 Jordan Skalisky - Scott Wanner - Bradford Howe - Kira Mauseth, "Religious Coping, Resilience, and Involuntary Displacement: A Mixed-Methods Analysis of the Experience of Syrian and Palestinian Refugees in Jordan", Psychology of Religion and Spirituality, Advance Online Publication, 2020, https://doi.org/10.1037/rel0000390

79 Halil Ekşi, a.g.e., 2001. 
acceptable for $\mathrm{GFI}=.94, \mathrm{AGFI}=.93, \mathrm{RMSEA}=.05, \mathrm{NFI}=.93, \mathrm{TLI}=.96, \mathrm{CFI}$ $=.96, \mathrm{RMR}=.04, \mathrm{IFI}=.96, \mathrm{SRMR}=.04$. It shows that the model is within the bounds of harmony and that it is valid. Figure 3 shows the steps to be followed step by step in the mediation test.

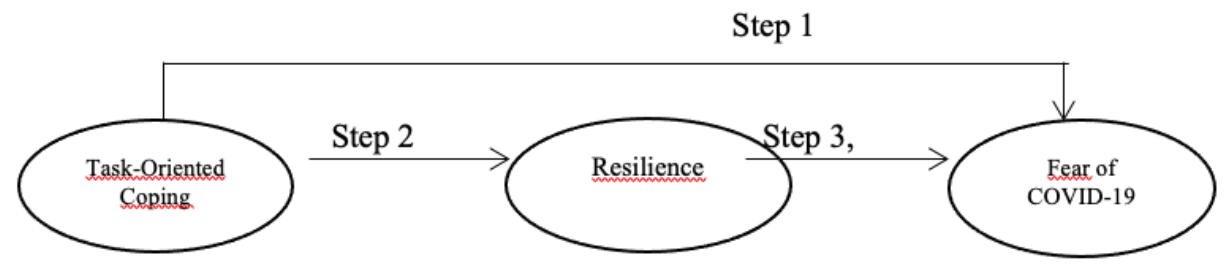

Figure 3. Mediating role of resilience in the relation between task-oriented coping and fear of COVID-19

The Sobel test results on the mediating role of resilience in the relation between task-oriented coping and the fear of COVID-19 are given in Table 11.

Table 11. The results of the Sobel test on the mediating role of resilience in the relation between task-oriented coping and the fear of COVID-19

\begin{tabular}{c|c|c|c|c|c|}
\hline Steps & Variables & $\boldsymbol{t}$ & $\boldsymbol{S H}$ & $\boldsymbol{\beta}$ & $\boldsymbol{p}$ \\
\hline Step 1 & Fear of C-19 $\leftarrow$ Task-Oriented C. & -3.233 & .045 & -.13 & $.001^{*}$ \\
Step 2 & Psy. Resilience $\leftarrow$ Task-Oriented C. & 12.298 & .042 & .55 & $* * *$ \\
Step 3 & Fear of C-19 $\leftarrow$ Psy. Resilience & -8.472 & .051 & -.36 & $* * *$ \\
Step 4 & Fear of C-19 $\leftarrow$ Task-Oriented C. & 1.196 & .043 & .05 & .232 \\
& Fear of C-19 $\leftarrow$ Psy. Resilience & -8.901 & .051 & -.37 & $* * *$ \\
\hline
\end{tabular}

$* * * p<.001, * p<.05$

Table 11 shows the results of the Sobel mediating role test. Analyzes were made on the total score. In the first step, task-oriented coping is a meaningful predictor of COVID-19 fear. In the second step, task-oriented coping is a significant predictor of resilience. In the third step, resilience is a significant predictor of COVID -19 fear.Based on the results of the first three phases, a mediating role of resilience has been identified in the relationship between task-oriented coping and the fear of COVID-19. Moreover, in the fourth stage, it was concluded that resilience had a fully mediating role in the relationship between task-oriented coping and the fear of COVID-19. 


\section{Discussion}

\section{Demographic Variables}

Due to fear, uncertainty, threat, and social isolation, COVID-19 affects individuals regardless of gender, race, ethnicity, or social class and causes various difficulties. ${ }^{80}$ However, their effects may vary according to demographic characteristics. In this study, women were found to have a higher level of COVID-19 fear than men. When looking at the COVID-19 reviews, women have higher stress levels, anxiety, and depression ${ }^{81}$ and feel more severe anxiety and fear about COVID-19 than men. ${ }^{82}$ Also, it has been found that women are more afraid of infection or that a loved one is infected, that it is right to restrict people's freedom to prevent the spread of the virus ${ }^{83}$ and show higher levels of psychological distress than men. ${ }^{84}$

Women pay more attention to their inner experiences; their perceptions and emotions are more fragile and sensitive. They are more vulnerable to depression, anxiety, and loneliness. Women have higher levels of depression, anxiety, and loneliness than men is therefore thought to be related to their gender characteristics. ${ }^{85}$ It is understandable, in this case, that women are more afraid of COVID-19. Besides, women are mostly people who are caring for children, the elderly, and the disabled. As a result, fear levels may be further exacerbated by social isolation and close contact with groups at risk for COVID-19. ${ }^{86}$

80 Craig Polizzi - Steven Jay Lynn - Andrew Perry, "Stress and Coping in The Time Of COVID-19: Pathways to Resilience and Recovery", Clinical Neuropsychiatry, vol. 17, no. 2, 2020, p. 59-62.

81 Cuiyan Wang et. al., a.g.m., p. 1729.

82 Lars Gerhold, COVID-19: Risk perception and coping strategies, March 2020; Long Huang et al., "Emotional Responses and Coping Strategies in Nurses and Nursing Students During COVID-19 Outbreak: A Comparative Study", PLoS ONE, vol. 15, no. 8, 2020, e0237303; Sherman A. Lee et al., "Clinically Significant Fear and Anxiety Of COVID-19: A Psychometric Examination of The Coronavirus Anxiety Scale", Psychiatry Research, 2020, 113112; Abdulkadir Haktanır - Tolga Seki - Bülent Dilmaç, a.g.m., p. 5-6.

83 Luca Simione - Camilla Gnagnarella, "Differences Between Health Workers and General Population in Risk Perception, Behaviors, and Psychological Distress Related to COVID-19 Spread in Italy", Frontiers in Psychology, vol. 11, 2020, p. 2166.

84 Jianyin Qiu et. al., a.g.m., e100213corr1.

85 Wenbin Gao - Zhiyan Chen - Yiniu Wang, "Analysis on The Influence and Change Trend of Public Mentality During Sars Epidemic”, Chinese Mental Health Journal, vol. 17, no. 9, 2003, p. 594-596.

86 Anastasia Topalidou - Gill Thomson - Soo Downe, "COVID-19 And Maternal Mental Health: Are We Getting the Balance Right?”, medRxiv, 2020. 
Among stress-related events, women are mainly affected by their health and family life; men, on the other hand, are seen to be involved in their financial and work-related lives. In addition, while women prefer more emotional and avoidant coping methods, men prefer logical ways of coping. ${ }^{87}$ In this study, emotion-oriented and avoidant coping scores of women were found to be higher than men; on the other hand, task-oriented coping scores of males were found to be higher than females. Considering the literature, women use emotional coping styles more than men, especially during of stressful life events ${ }^{88}$; on the other hand, results show that males use problem-based coping techniques more frequently. ${ }^{89}$ Male participants who use a task-oriented style of coping experience a lower level of stress. Therefore, it can be said that the difference in coping techniques used is one reason why women are more afraid of COVID-19 than men. Studies on the relationship between stress management methods and mental health show that emotional-oriented coping/avoidant coping strategies are associated with psychological symptoms such as fear and anxiety. ${ }^{90}$ This situation supports the heightened fear of COVID-19 in women.

Avoidant coping style is a tendency based on social distortion, rejection, and distraction to not face a stressful situation. The avoidant coping style includes activities and cognitive changes to keep a person away from stressful situations, such as distraction. ${ }^{91}$ Inadequate coping resources and feelings of powerlessness led individuals to emotional and avoidant strategies. ${ }^{92}$ Women who use emotional-oriented coping more are expected to use more avoidant coping as well. This study shows that there is a positive relationship between avoidant coping and emotional coping.

87 M. Pilar Matud, "Gender differences in stress and coping styles", Personality and Individual Differences, vol. 37, no. 7, 2004, p. 1401-1415

88 Ahmet Gül et al., "Major Depresyon Hastalarında Çocukluk Çağı Travmaları ve Başa Çıkma Tutumlarının Cinsiyete Özgü Farklılıkları”, Türk Psikiyatri Dergisi, cilt 28, say1 4, 2017, s. 246-54; June E. Higgins - Norman S. Endler, "Coping, Life Stress, and Psychological and Somatic Distress", European Journal of Personality, vol. 9, 1995, p. 253-270; Ramazan Konkan et al., "İntihar Girişiminde Bulunan Kişilerde Başa Çıkma Tutumları", Archives of Neuropsychiatry/Noropsikiatri Arsivi, cilt 51, say1 1, 2014, s. 46-51; Mike Soderstrom et al., "The Relationship of Hardiness, Coping Strategies, and Perceived Stress to Symptoms Of Illness", Journal of Behavioral Medicine, vol. 23, 2000, p. 311-328.

89 Ahmet Gül et al., a.g.m., s. 246-54; June E. Higgins - Norman S. Endler, a.g.m., p. 253-270.

90 June E. Higgins - Norman S. Endler, a.g.m., p. 253-270.

91 Normen S. Endler - James D. A. Parker, "State and Trait Anxiety, Depression and Coping Styles", Australian Journal of Psychology, vol. 42, no. 2, 1990, p. 207-220.

92 Martin M. Smith et al., "Coping Strategies and Psychological Outcomes: The Moderating Effects of Personal Resiliency”, The Journal of Psychology, vol. 150, no. 3, 2016, p. 318-332. 
Individuals turn to religion more in stressful situations as a coping method. ${ }^{93}$ However, there are conflicting results in the literature on whether religious styles of coping differ by gender. According to some studies, women use more positive and negative religious coping than men $^{94}$; according to other studies, men use more positive and negative religious coping than women. ${ }^{95}$ In this study, negative religious coping levels of males were found to be higher than females. This finding is consistent with other findings that males use more negative religious coping styles than females. ${ }^{96}$ The level of religiosity was not addressed in this study. This difference, however, may be due to individuals' level of religiosity or their intrinsic religious orientation. According to the literature, women have a higher level of religiosity ${ }^{97}$ and an intrinsic religious orientation ${ }^{98}$ than men. Negative religious coping strategies are negatively related to religiosity. ${ }^{99}$ As a result, it is understandable that men use more negative religious coping strategies, and this is consistent with the literature.

Resilience is another variable considered in terms of gender. In the literature, there are conflicting findings on the relationship between resilience and gender. In some studies, there is no difference in resilience between men and women. ${ }^{100}$

93 Kenneth. I. Pargament - Curtis R. Brant, a.g.e., p. 124.

94 Christopher Alan Lewis - John Maltby - Liz Day, "Religious Orientation, Religious Coping and Happiness Among UK Adults", Personality and Individual Differences, vol. 38, no. 5, 2005, p. 1193-1202.

95 Dorte Hvidtjørn et al., "Religiousness and Religious Coping in A Secular Society: The Gender Perspective", Journal of Religion and Health, vol. 53, no. 5, 2014, p. 1329-1341.

96 Halil Ekşi, a.g.e., 2001; Naci Kula, "İstenmedik ve Beklenmedik Olaylarla Karşılaşan Bireylere Yönelik Moral ve Manevî Desteğin Önemi (Deprem ve Bedensel Engellilik Örneği)”, Din Bilimleri Akademik Araştırma Dergisi, cilt 6, sayı 3, 2006, s. 73-94.

97 Asım Yapıcı, Ruh Sağlı̆̆l ve Din Psiko-Sosyal Uyum ve Dindarlık, Adana, Karahan Kitabevi, 2007, s. 178; Ayşe Şentepe, a.g.m., 193.

98 Sema Ercüyel, "Dini Yönelim ve Başa Çıkma”, Turkish Studies, cilt 13, sayı 2, 2018, s. 393 412; John Maltby - Liza Day, "Religious Orientation, Religious Coping and Appraisals of Stress: Assessing Primary Appraisal Factors in The Relationship Between Religiosity and Psychological Well-Being”, Personality and Individual Differences, vol. 34, 2003, s. 1213.

99 Ali Ayten - Refik Yıldız, "Dindarlık, Hayat Memnuniyeti İlişkisinde Dinî Başa Çıkmanın Rolü Nedir? Emekliler Üzerine Bir Araştırma”, Dinbilimleri Journal, cilt 16, sayı 1, 2016, s. 297.

100 Filiz Arslan - Tuncay Ayas, "Din ve Psikoloji Eğitimi Alan Öğrencilerin Psikolojik Sağlamlık ve Affedicilik Düzeylerinin Çeşitli Değişkenler Açısından Incelenmesi”, Sakarya Üniversitesi Ĕ̆itim Fakültesi Dergisi, sayı 38, Aralık 2019, s. 1-29; Nesrin Y1ldı-Türker, "Yetişkinlerde Dindarlık ve Psikolojik Sağlamlık Ilişkisi Üzerine Bir Araştırma”, (Yayımlanmamış Yüksek Lisans Tezi), Uludağ Üniversitesi, Bursa, 2018. 
In other studies, girls' resilience scores were significantly lower than boys. ${ }^{101} \mathrm{In}$ this study, the level of resilience among men was higher than among women. This may be due to the fact that men are using more task-oriented coping styles. In addition, a study conducted during the pandemic found that the female gender was significantly associated with higher psychological impacts, higher levels of stress, anxiety, and depression. ${ }^{102}$ This finding can be explained by the negative impact of the fear of COVID-19 on the resilience of women.

Having a chronic illness can make people feel more vulnerable to any disease. For this reason, people with chronic diseases are expected to be more afraid of COVID-19. In this study, those with chronic diseases were found to have higher levels of COVID-19 fear than those without chronic disease. Other studies conducted during the COVID-19 pandemic have shown that having a chronic disease is associated with increased anxiety about COVID-19, higher levels of depression, stress, anxiety, and health anxiety. ${ }^{103}$

Increases in social fears due to COVID-19 and decreases in social and economic activity can adversely affect the psychosocial structure. ${ }^{104}$ Even for those who are not infected, a pandemic may be a significant stressor, especially, in chronic anxiety and economic difficulties. ${ }^{105}$ Indeed, the outbreak of COVID-19 has had economic and psychosocial consequences with profound psychological effects on all individuals worldwide. ${ }^{106}$ In this study, those with low-income status were found to have higher levels of COVID-19 fear than those with high income. Understandably, those with low incomes are more afraid of COVID-19. A stable family income is a protective factor against anxiety caused by COVID-19. ${ }^{107}$ People with low incomes are more likely to lose their jobs because they work in temporary jobs or mostly in the private sector. Moreover, given that many of

101 Juan Li - Ting Wang - Jinwen Wang, "Research on The Relationship Between College Students' Psychological Resilience and Coping Style Under the Perspective of Positive Psychology", Advances in Social Science, Education and Humanities Research, vol. 321, 2019.

102 Cuiyan Wang et. al., a.g.m., p. 1729.

103 Gaetan Mertens et al., a.g.m., 102258; Cuiyan Wang et. al., a.g.m., p. 1729; Zhu et al., 2020.

104 Samantha K. Brooks et al., "The Psychological Impact of Quarantine and How to Reduce It: Rapid Review of The Evidence", The Lancet, vol. 395, no. 10227, March 2020, p. 912-920.

105 Jay. J. Van Bavel et al., "Using Social and Behavioural Science to Support Covid-19 Pandemic Response", Nature Human Behavior, vol. 4, 2020, p. 460-471.

106 Amir. H. Pakpour - Mark D. Griffiths, "The fear of COVID-19 and its Role in Preventive Behaviors", Journal of Concurrent Disorders, vol. 2, no. 1, 2020, p. 58-63.

107 Wenjun Cao et al., "The Psychological Impact of the COVID-19 Epidemic on College Students in China”, Psychiatry Research, vol. 287, May 2020, 112934. 
them do not have additional income, concerns about their livelihoods may cause them to fear even more COVID-19.

\section{Correlations Between Variables}

Fear in the face of COVID-19 can be considered a natural reaction, as the pandemic is a significant threat. Panic and anxiety caused by the epidemic are, however, significant threats in the background. ${ }^{108}$ During pandemics, the anxiety level of healthy individuals increases due to fear, and the symptoms of individuals with previous psychological disorders increase. ${ }^{109}$ During the COVID-19 pandemic, individuals with high levels of depression ${ }^{110}$ and anxiety ${ }^{111}$ were identified. Another study found that some Chinese faced acute PTSD during the outbreak of COVID-1912 In a survey study conducted in China during the first outbreak of COVID-19, 53.8\% of respondents rated the outbreak's psychological impact as moderate or severe. ${ }^{113}$ In Wuhan, it was found that individuals had high moderate, and severe symptoms of anxiety. ${ }^{114}$ According to a Turkish study, one in every four participants has anxiety symptoms, and one in every three has moderate to severe hopelessness symptoms. ${ }^{115}$ In another study conducted to examine differences in the same group before and after the COVID-19 declaration, it was found that negative emotions such as anxiety and anger and sensitivity to social risks increased, positive emotions and life satisfaction decreased after the pandemic. ${ }^{116}$ Based on this research results, it can be said that resilience is an essential factor in terms of the pandemic. As determined in our study, resilience predicts the fear of COVID-19, and as resilience increases, the fear of COVID-19 decreases. In fact, according to the literature, as the level of resilience increases, depression and

108 Suzanne M. Anderson, Developing Resilience-The Danger and Opportunity Of COVID-19 for International School Educators (Part 2), 19 March 2020.

109 Jun Shigemura et al., a.g.m., p. 281-282.

110 Zhu et al., 2020

111 Wenjun Cao et al., a.g.m., 112934; Zhu et al., 2020.

112 Luna Sun et al., "Prevalence and Risk Factors of Acute Posttraumatic Stress Symptoms During The COVID-19 Outbreak in Wuhan, China", medRxiv, 2020.

113 Cuiyan Wang et. al., a.g.m., p. 1729.

114 Qian et al., a.g.m.

115 Yeşim Erdoğdu - Filiz Koçoğlu - Celil Sevim, “COVID-19 Pandemisi Sürecinde Anksiyete ile Umutsuzluk Düzeylerinin Psikososyal ve Demografik Değişkenlere Göre İncelenmesi”, Klinik Psikiyatri Dergisi, vol. 23, 2020, s. 1.

116 Sijia Li et al., "The Impact Of COVID-19 Epidemic Declaration on Psychological Consequences: A Study on Active WEIBO Users", International Journal of Environmental Research and Public Health, vol. 17, no. 6, 2020, p. 2032. 
anxiety decrease, the progression of diseases slow down, and the level of stress decreases. ${ }^{117}$ In addition, resilience makes it easier to control stress, depression, and anxiety. ${ }^{118}$ There is a significant relationship between high anxiety level and low resilience. ${ }^{119}$ Resilience is, therefore, an essential concept for coping with COVID-19.

According to the study, task-oriented coping and COVID-19 fear have a negative relationship, and resilience plays a mediating role between them. In other words, the positive relationship between resilience and task-oriented coping has the effect of reducing the level of fear of COVID-19. Individuals with low resilience are quickly traumatized and isolated. Individuals with a high level of resilience, on the other hand, evaluate existing opportunities for improvement and better adaptation. ${ }^{120}$ This situation shows that resilience people use more task-oriented coping styles. As a result, people who are resilient and rely on task-oriented coping styles are less likely to develop fear of COVID-19.

Compelling and traumatizing life events that cause fear, such as a pandemic, require coping with the situation. The individual can try many methods to deal with the adverse situation he/she is experiencing. However, task-oriented coping styles are more effective than emotional coping styles in dealing with problems. ${ }^{121}$ In this study, fear of COVID-19 decreased as task-oriented coping increased. A study in China found that positive coping styles and increased social support were associated with low psychological distress. ${ }^{122}$ However, Huang et al. ${ }^{123}$ found that a task-oriented approach to COVID-19 is associated with more fear; the more people fear, the more task-oriented coping, and the more they are with, the more emotion-oriented coping.

117 Silvia Fernanda Cal et al., "Resilience in Chronic Diseases: A Systematic Review", Cogent Psychology, vol. 2, no. 1, April 2015, 1024928.

118 Kathryn M. Connor - Wei Zhang, "Recent Advances in The Understanding and Treatment of Anxiety Disorders. Resilience: Determinants, Measurement, and Treatment Responsiveness", CNS Spectrums, 11, 2006, p. 5-12.

119 Elif Baykal, "COVID-19 Bağlamında Psikolojik Dayanıklılık, Kaygı ve Yaşam Doyum İlişkisi”, International Journal of Social and Economic Sciences, cilt 10, say1 2, 2020, s. 68-80.

120 Judith Lewis Herman, "Trauma and Recovery", The Aftermath of Violence-From Domestic Abuse to Political Terror (Chapter 3), Hachette, UK, 2015.

121 Marsha Mailick Seltzer - Jan S. Greenberg - Marty Wyngaarden Krauss, "A Comparison of Coping Strategies of Aging Mothers of Adults with Mental Illness or Mental Retardation", Psychology and Aging, vol. 10, no. 1, 1995, p. 64-75.

122 Hua Yu et al., "Coping Style, Social Support, and Psychological Distress in The General Chinese Population in The Early Stages of the COVID-2019 Epidemic", April 2020.

123 Long Huang et al., a.g.m., e0237303. 
Coping styles are essential when adapting to life's challenging events. However, it is not only the coping styles used by the individual that reveal a successful coping process. The participation of external resources, such as internal and social support, such as courage, optimism, control, and the nature of the problem, determines the coping process's success. ${ }^{124}$ Indeed, a study in Germany has shown that most people see COVID-19 as a global disaster that will seriously affect many people for a long time, but at the same time, they feel that risks can be reduced and controlled. They have also been found to be very concerned about COVID-19, but less afraid of becoming infected. ${ }^{125}$ Another study found that those with suspected infection use more negative coping styles. ${ }^{126}$ The virus can frighten people as it poses a risk of death. ${ }^{127}$ As can be seen, Germans listen to expert advice, believe that there is nothing to do but wait, and use more task-oriented coping styles to deal with the activities they will engage in. ${ }^{128}$ In this case, it can be argued that personal control is a variable that directly affects task-oriented coping. ${ }^{129}$ In a task-oriented approach, individuals are trying to reduce stress by trying methods such as getting suggestions and advice, developing new skills, planning, and dealing with other jobs. ${ }^{130}$ When the perceived threat is severe, the threat may be a motivating factor for activating the control mechanism. ${ }^{131}$ For example, a study conducted in Vietnam found that risk perception is the primary driver of a public wearing a medical mask. ${ }^{132}$ In another study, it was found that most individuals who use task-oriented coping styles try to act on the situation by following expert advice and consider storing essential foods as necessary. ${ }^{133}$

124 Shelly E. Taylor - A. Peplau Letitia - David O. Sears, a.g.e., p. 466-469.

125 Lars Gerhold, a.g.m., March 2020.

126 Hua Yu et al., a.g.m., April 2020.

127 Craig Polizzi - Steven Jay Lynn - Andrew Perry, a.g.m., p. 59-62.

128 Lars Gerhold, a.g.m., March 2020.

129 Aygül Tunç-Aksan - Cem Ali Gizir, "Meme Kanseri Tanısı Almış Kadınların Hastalık Temsilleri ve Başa Çıkma Tarzları ile Kaygı ve Depresyon Düzeyleri Arasındaki İlişkilerin İncelenmesi”, Turkish Psychological Counseling and Guidance Journal, cilt 9, say1 54, 2019, s. 623-658.

130 Betül Aydın - Seval İmamoğlu, "Stresle Başa Çıkma Becerisi Geliştirmeye Yönelik Grup Ça1ı̧̧ması”, Marmara Üniversitesi Atatürk Eğitim Fakültesi Ĕ̆itim Bilimleri Dergisi, sayı 14, Aralık 2001, s. 41-52.

131 Sijia Li et al., a.g.m., p. 2032.

132 Toan Luu Duc Huynh, “The More I Fear About COVID-19, The More I Wear Medical Masks: A Survey on Risk Perception and Medical Masks Uses", medRxiv, 2020.

133 Lars Gerhold, a.g.m., March 2020. 
As we have seen, there is no definitive formula or user guide on how to deal with the current global pandemic. Numerous coping strategies, such as behavioral activation, acceptance-based coping, and mindfulness, can reduce stress and promote resilience and recovery. These strategies can help individuals gain meaning and develop distress tolerance. ${ }^{134}$

The process of choosing coping styles depends on the source of stress and the individual's nature. Task-oriented coping styles solve the problem when the source of stress is perceived as controllable; when the source of stress is perceived as uncontrollable, emotional-oriented coping styles are used to manage the situation. ${ }^{135}$ Our study found that task-oriented coping styles are used more than other coping styles (average: 3.64). This finding may indicate that the individuals participating in our study consider the pandemic to be more controllable. There is, however, no application that will put an end to the process at the moment. The feeling of helplessness caused by the possibility of prolonging the process can trigger emotion-oriented coping, a submissive approach. Other studies have shown a direct and positive relationship between acute/chronic disease perception and emotional coping style. ${ }^{136}$

Temporary solutions to suppress the emotions of the individual, such as emotional handling, escape-avoidance ${ }^{137}$, which are used in emotional-oriented coping styles, not only prevent the individual from feeling sad and distressed but also prevent one from tackling the problem. ${ }^{138}$ Studies have shown that task-oriented coping styles are more effective than emotional-oriented coping styles. Using emotional-oriented coping styles is associated with various psychological symptoms ${ }^{139}$ and high psychological distress levels. ${ }^{140}$ In this study, it was deter-

134 Craig Polizzi - Steven Jay Lynn - Andrew Perry, a.g.m., p. 59-62.

135 Charles. S. Carver - Michael F. Scheier - Jagdish. K. Weintraub, “Assessing Coping Strategies: A Theoretically Based Approach”, Journal of Personality and Social Psychology, vol. 56, 1989, p. 267-283.

136 Monique Heijmans, “The Role of Patients' Illness Representations in Coping and Functioning with Addison's Disease”, British Journal of Health Psychology, vol. 4, no. 2, 1999, p. 137-149; Rebecca C. Knibb - S. L. Horton, "Can Illness Perceptions and Coping Predict Psychological Distress Amongst Allergy Sufferers?”, British Journal of Health Psychology, vol. 13, no. 1, 2008, p. 103-119; Aygül Tunç-Aksan - Cem Ali Gizir, a.g.m., s. 623-658.

137 Richard S. Lazarus - Susan Folkman, a.g.e., p. 141-151.

138 Richard S. Lazarus, a.g.m., p. 234-247.

139 Andrew G. Billings - Rudolf H. Moos, "Coping, Stress and Social Resources Among Adults with Unipolar Depression”, Journal of Personality and Social Psychology, vol. 46, no. 4, 1984, p. 877-891.

140 Ora Gilbar - Avi HevroniI, "Counterfactuals, Coping Strategies and Psychological Distress Among Breast Cancer Patients", Anxiety, Stress, and Coping, vol. 20, no. 4, 2007, p. 383-392. 
mined that, as the fear of COVID-19 increases, emotional-oriented coping also increases. Consistent with this finding, Yu et al. ${ }^{141}$ also found that emotional coping increased as stress levels increased during the pandemic.

Fear of COVID-19 has brought security and avoidance behavior along with concern about many issues. ${ }^{142} \mathrm{Yu}$ et al. ${ }^{143}$ found that individuals who use negative coping styles such as problem-avoidance and self-reproach have higher psychological distress levels. This study found that the more avoidant coping increased, the more fear of COVID-19 increased. The literature shows that avoidant or passive coping styles are associated with negative health outcomes. ${ }^{144}$

People affected by negative life events tend to turn to religion to reduce their anxiety and find meaning or explanation. ${ }^{145}$ For example, during this epidemic period, it has been observed that the search for prayers on Google as a religious coping activity has increased. ${ }^{146}$

It is argued that people tend to use religion to cope with the crisis. ${ }^{147} \mathrm{Al}-$ though a significant relationship between positive religious coping and fear of COVID-19 has not been identified in this study, the relatively high average positive religious coping score (3.27) is an important finding (Total scale score is 4). Given that this study was conducted during the pandemic, this may be due to the high use of positive religious coping by all individuals.

There is a positive correlation between negative religious coping and fear of COVID-19. A recent study on COVID-19 also found that, as COVID-19's anxiety increases, negative religious coping increases. ${ }^{148}$ Thus, even though reli-

141 Hua Yu et al., a.g.m., April 2020.

142 Gaetan Mertens et al., a.g.m., 102258.

143 Hua Yu et al., a.g.m., April 2020.

144 Carol S. Stilley et al., "Individual and Environmental Correlates and Predictors of Early Adherence and Outcomes After Liver Transplantation”, Progress in Transplantation, vol. 20, no. 1, 2010, p. 58-66.

145 Jeanet Sinding Bentzen, “Acts of God? Religiosity and Natural Disasters Across Subnational World Districts", The Economic Journal, vol. 129, no. 622, 2019, p. 2295-2321; Jeanet Sinding Bentzen, "In Crisis, We Pray: Religiosity and the COVID-19 Pandemic", CEPR Discussion Papers, 2020, p. 14824; Kenneth. I. Pargament et al., "Religious Coping Among the Religious: The Relationships Between Religious Coping and Well-Being in A National Sample of Presbyterian Clergy, Elders, And Members", Journal for the Scientific Study of Religion, vol. 40, 2001, p. 497498.

146 Jeanet Sinding Bentzen, a.g.m., 2020, p. 14824.

147 Jeanet Sinding Bentzen, a.g.m., p. 2295-2321; Kenneth. I. Pargament et al., a.g.m., p. 497498. 148 Sherman A. Lee et al., a.g.m., p. 113112. 
gions have provided a sense of comfort and security throughout human history, religion's role in the pandemic is not always productive, but even sometimes unproductive. Prohibition of religious gatherings or mass worship is one of them.

Restrictions to prevent the spread of the virus should also consider the theological, social, and existential features of religious traditions. Otherwise, if there is no cooperation with reliable religious authorities, religious communities can be alienated which can have devastating consequences in pandemics requiring unity of thought and action. During the pandemic, severe restrictions or prevention of religious activity in some countries have caused such crises; alternative measures may be more appropriate, such as keeping the rites practiced by some countries in church gardens, allowing people to watch from their cars from a distance. This situation requires the ability to bridge different perspectives to reduce public health risks effectively. ${ }^{149}$ Otherwise, individuals may think that this is also God's punishment, and they may have started to dealing more with negative religious coping. Decreased social support is a risk factor for psychological distress as it leaves individuals vulnerable to stress. ${ }^{150}$

There is a positive and significant relationship in the literature between resilience and positive coping styles. The predictive effect of resilience on positive coping styles is higher than the negative coping style. ${ }^{151}$ resilience was positively associated with positive religious coping and negatively associated with negative religious coping in this study. Psychologically sound people are mostly people with high adaptability skills, developed internal locus of control, alternative perspectives and intellectual skills, flexible and religious believers with a calm mood. ${ }^{152}$

High levels of resilience are essential for individuals to cope with adverse events in their lives, to adapt to the situation ${ }^{153}$, to increase well-being ${ }^{154}$ and to

149 R. Istratii, Restricting Religious Practice in The Era Of COVID-19: A De-Westernised Perspective on Religious Freedom with Reference to The Case of Greece, 15 April 2020.

150 Fatih Ozbay et al., "Social support and resilience to stress: from neurobiology to clinical practice”, Psychiatry (Edgmont (Pa.: Township)), vol. 4, no. 5, 2007, p. 35-40.

151 Juan Li - Ting Wang - Jinwen Wang, a.g.m., 2019.

152 Emmy E. Werner - Ruth S. Smith, Vulnerable but invincible: A longitudinal study of resilient children and youth, New York, McGraw-Hill, 1982.

153 Özlem Kararırmak, a.g.m., s. 129-138.

154 Jacqueline Scali et al., "Measuring Resilience in Adult Women Using The 10-Items Connordavidson Resilience Scale (CD-RISC). Role of Trauma Exposure and Anxiety Disorders", PloS One, vol. 7, 2012, p. e39879; Minden B. Sexton - Michelle R. Byrd - Silvia von Kluge, "Measuring Resilience in Women Experiencing Infertility Using The CD-RISC: Examining 
reduce stress. ${ }^{155}$ Individuals who have the power to cope with problems without impairing their functionality have a high level of resilience. ${ }^{156}$ This study found that, as task-oriented coping increased, resilience increased. Individuals with high resilience use social support resources and task-oriented coping styles, while individuals with low resilience prefer avoiding styles. ${ }^{157}$ Frankl argues that people have the freedom to choose their attitude, regardless of the conditions. ${ }^{158}$ Therefore, instead of thinking that events are controlled purely by external factors, individuals who take control of events by thinking that they can control events more easily adapt to negative situations and become more resistant to such events. ${ }^{159} \mathrm{In}$ literature, having effective problem-solving skills ${ }^{160}$ is one factor associated with resilience. People with a high level of resilience can cope more effectively and easily with difficulties, adapt more easily to changes due to traumatic events, use problem-solving styles ${ }^{161}$, and have a higher level of optimism. ${ }^{162}$

Resilience reduces emotional coping with stressful life events. ${ }^{163}$ This study also found that as resilience increases, task-oriented coping increases while emotional-oriented coping decreases. Positive and negative emotions have a direct

Infertility-Related Stress, General Distress, And Coping Styles", Journal of Psychiatric Research, vol. 44, 2010, p. 236-241.

155 Dmitry M. Davydov et al., "Resilience and mental health", Clinical Psychology Review, vol. 30, 2010, p. 479-495.

156 George A. Bonanno et al., "Trajectories of Resilience, Depression, and Anxiety Following Spinal Cord Injury", Rehabilitation Psychology, vol. 57, 2012, p. 236-247.

157 Suzanne. C. Kobasa - Mark. C. Puccetti, "Personality and Social Resources in Stress Resistance", Journal of Personality and Social Psychology, vol. 45, no. 4, 1983, p. 839-850.

158 Victor Emile Frankl, Duyulmayan Anlam Çı̆̆glı̆̆l, çev. Selçuk Budak, Ankara, Öteki Yayınevi, 1994, s. 41.

159 Özlem Karaırmak - Rahşan Siviş-Çetinkaya, a.g.m., s. 30-43.

160 Michael Rutter - David Quinton, "Long-Term Follow-Up of Women Institutionalized in Childhood: Factors Promoting Good Functioning in Adult Life", British Journal of Developmental Psychology, vol. 18, 1984, p. 191-204; Emmy E. Werner - Ruth S. Smith, a.g.e., 1982.

161 Kathryn M. Connor - Jonathan R. T. Davidson - Li-Ching Lee, "Spirituality, Resilience, and Anger in Survivors of Violent Trauma: A Community Survey", Journal of Traumatic Stress, vol. 16, 2003, p. 487-494.

162 Hei-Sung Lee et al., "Correlates of Resilience in The Face of Adversity for Korean Women Immigrating to The U.S.", Journal of Immigrant and Minority Health, vol. 10, 2008, p. 415422.

163 Margaret Beasley - Ted Thompson - John Davidson, "Resilience in Response to Life Stress: The Effects of Coping Style and Cognitive Hardiness", Personality and Individual Differences, vol. 34, 2003, p. 77-95. 
effect on resilience. ${ }^{164}$ One of the positive personality traits associated with resilience is positive emotionality. ${ }^{165}$ However, emotional coping is related to a negative effect. People with low resilience are both negative and pessimistic. They are, therefore, more prone to negative emotions. ${ }^{166}$ Individuals with a high level of resilience, on the other hand, have a lower level of a perceived threat to themselves and the world. Therefore, individuals with a high level of resilience do not care much about the negative meaning of the situation they live in, as they can reduce the event's impact. ${ }^{167}$ In other words, individuals with a high degree of resilience tend to increase their positive emotions. ${ }^{168}$

There is a relationship between religious coping dimensions and stress coping styles. ${ }^{169}$ Ekşi ${ }^{170}$, found a positive relationship between positive religious coping styles and task-oriented coping, negative religious coping styles, and avoiding coping styles (such as denial, behavioral disengagement, alcohol/drug use). In this study, it was found that there is a positive relationship between task-oriented coping and positive religious coping, emotional coping, and negative religious coping. However, no significant relationship has been found between avoidant coping and religious coping styles.

In conclusion, the development of COVID-19 caused fear and panic in society. To take control of the pandemic, it is also necessary to manage fear and panic. Researches investigating the effects of COVID-19 are therefore of great importance. Because there is a rapid accumulation of work on the medical aspects of COVID-19, there is little research into the psychological impact of COVID-19. However, to overcome this crisis, it is very important not to ignore the psychological impact of the epidemic on individuals and society. Because even after the epidemic ends, psychological consequences can manifest themselves for a long

164 Özlem Karaırmak - Rahşan Siviş-Çetinkaya, a.g.m., s. 30-43.

165 Michele M. Tugade - Barbara L. Frederickson, "Resilient Individuals Use Positive Emotions to Bounce Back from Negative Emotional Experiences", Journal of Personality and Social Psychology, vol. 86, no. 2, 2004, p. 320-333.

166 Juan Li - Ting Wang - Jinwen Wang, a.g.m., 2019.

167 George A. Bonanno - Camille B. Wortman - Randolph M. Nesse, "Prospective Patterns of Resilience and Maladjustment During Widowhood", Psychology and Aging, vol. 19, 2004, p. 260-271.

168 Michele M. Tugade - Barbara L. Frederickson, a.g.m., p. 320-333.

169 Ahmet Canan Karakaş - Mustafa Koç, "Stresle Başa Çıkma ve Dini Başa Çıkma Yöntemleri Arasındaki İlişkinin Çeşitli Değişkenler Açısından İncelenmesi”, Itobiad: Journal of the Human \& Social Science Researches, cilt 3, say1 3, 2014, s. 610-631.

170 Halil Ekşi, a.g.e., 2001. 
time. ${ }^{171}$ Therefore, large-scale longitudinal trauma studies and multidisciplinary studies are needed to better understand the effects of the COVID-19 crisis. ${ }^{172}$

As the COVID-19 epidemic, a global health crisis, causes major behavioral changes and psychological burdens, informations from the social and behavioral sciences can help take appropriate steps in this process. ${ }^{173}$ For example, meditation-based interventions may help cope with COVID-19 disease, according to one study result. ${ }^{174}$ According to our findings, the fear of COVID-19 decreases as positive coping styles such as task-oriented coping are used and the level of resilience rises. Therefore, interventions such as supporting individuals' coping resources and increasing their resilience can help reduce the crisis. Otherwise, people without adequate coping resources may rely more on negative COVID-19 information because their negative emotions increase. ${ }^{175}$ Particularly at this point, the media can spread false information and increase fear, anxiety, and uncertainty. ${ }^{176}$ Therefore, patients should be trained in psychological skills to cope with anxiety, panic, and other emotional problems, and, where possible, mental health professionals should assist these patients. ${ }^{177}$ For this, psycho-education can be provided about the disorder that an individual is suffering from, such as panic, anxiety, or depression, as well as the relationship between these ailments and COVID. Educational programs or individual interviews aimed at teaching problem solving skills can be planned. Because it is a pandemic, it is possible that it will focus on online programs that can be used for online interviews and services that can be provided remotely, such as online therapy and online education. For example, the Ministry of Health also provides psychological support over the

171 Cyrus S. H. Ho - Cornelia Y. I. Chee - Roger. C. M. Ho, "Mental Health Strategies to Combat the Psychological Impact Of COVID-19 Beyond Paranoia and Panic", Annnals Academy Medicine, Singapore, vol. 49, no. 1, 2020, p. 155-160.

172 Danny Horesh - Adam. D. Brown, "Traumatic Stress in The Age Of COVID-19: A Call to Close Critical Gaps and Adapt to New Realities", Psychological Trauma: Theory, Research, Practice, and Policy, vol. 12, no. 4, 2020, p. 331-335.

173 Jay. J. Van Bavel et. al., a.g.m., p. 460-471.

174 Jiang Yanyu et al., "Meditation-Based Interventions Might Be Helpful for Coping with Coronavirus Disease 2019 (COVID-19)", 2020.

175 Jay. J. Van Bavel et. al., a.g.m., p. 460-471.

176 Dana Rose Garfin - Roxane Cohen Silver - E. Alison Holman, "The Novel Coronavirus (COVID-2019) Outbreak: Amplification of Public Health Consequences by Media Exposure", Health Psychology, vol. 39, no. 5, 2020, p. 355-357; Gaetan Mertens - Lotte Gerritsen - Stefanie Duijndam - Elske Salemink - Iris M. Engelhard, a.g.m., 102258.

177 Shuai Liu et al., "Online Mental Health Services in China During The COVID-19 Outbreak", The Lancet Psychiatry, vol. 7, no. 4, 2020, p. e17-e18. 
phone in Turkey. Some experts and associations working in mental health provide information and broadcasts on social media and websites.

Counselors, psychologists, and psychiatrists play critical roles in promoting resilience and coping. To increase endurance, interventions that focus on an individual's strengths can be developed and implemented. The client can be taught coping skills and guided on how to use his or her strengths. Issues such as "the meaning of life" can be studied, which can support both coping skills and resilience. Focusing on the elements that will give the invidual's life meaning can help get through the process more easily. Because there is a process by which losses are experienced, work on mourning can be done. Grief counseling can be provided to individuals who have lost their relatives due to COVID. If required, spiritual care services can be used to supplement studies in the field of mental health. Finally, by conducting a risk assessment or mental health screening across society, it is possible to determine what is essentially required for mental health. Thus, necessary interventions can be carried out.

\section{Conclusions}

COVID-19 has adverse psychological effect for individuals. According to the results of this study, demographic groups such as women, singles, and those with chronic diseases are at risk due to a high level of fear of COVID-19. As resilience increases, fear of COVID-19 declines. Also, resilience has been found to play a mediating role in the negative relationship between task-oriented coping and fear of COVID-19. As a result, higher fear of COVID-19 is associated with lower levels of resilience and ineffective coping methods.

\section{Limitations and Recommendations}

There are some limitations to this study. The majority of our sample is well-educated (i.e., undergraduate), and is between 20 and 60 years of age. Older people are known to be more susceptible to the COVID-19 virus, but only $0.4 \%$ of our sample is older than 60 years of age. Consequently, our results may not represent the highest risk group affected by COVID-19.

As another limitation, although the measuring instruments have good psychometric properties (due to the limitations posed by COVID-19 measures), our results do not claim to be generalizable to a wider population, as appropriate sampling is done using an online survey. Since this study was a cross-sectional study and did not provide causal information, changes in individual fear levels of COVID-19, coping attitudes, and resilience could not be detected. After the epidemic, this study can be replicated to detect the pandemic's long-term psycho- 
logical effects or to detect differences; different studies can be performed using other variables. To obtain more robust findings, a different research design and a more representative sample can be used. Studies may be conducted on infected patients, non-infected individuals, infected caregivers, and health professionals.

Since COVID-19 is still a relatively new phenomenon, is spreading rapidly, and restricts opportunities, there are not sufficient empirical data to reveal its psychological impact. To represent the general sample, studies with different sample groups and more participants are needed. In this study, coping behaviors were considered within the scales' scope, and no questions were asked about preventive behaviors. Preventive behaviors may also be addressed in the studies to be conducted.

In addition, in terms of content validity, it should be considered that the results obtained from the model in this study are limited to the answers given by the individuals who completed the questionnaire and the variables considered. However, current findings provide important early evidence of fear of COVID-19, resilience, and coping with COVID-19. As a result, fear of COVID-19 is associated with lower resilience levels and inefficient coping methods. As the virus is currently spreading throughout the world, current findings could potentially be used for further research worldwide. These findings can be used to understand and improve people's mental health during the pandemic.

\section{Conflict of Interest}

No commercial or financial contribution could be interpreted as a potential conflict of interest in this research.

\section{Acknowledgments}

We thank Prof. Dr. Abdülkerim BAHADIR and Prof. Dr. Adem ŞAHIN for their support during our research. We are also grateful to all the participants who volunteered to participate in our research at such a difficult time and spent time for our research. 


\section{References}

Alsolais, Abdullelah - Alquwez, Nahed - Alotaibi, Khalaf Aied - Alqarni, Aidah Sanad - Almalki, Mohammed - Alsolami, Fatmah - Almazan, Joseph Cruz, Jonas Preposi, "Risk Perceptions, Fear, Depression, Anxiety, Stress and Coping Among Saudi Nursing Students During The COVID-19 Pandemic", Journal of Mental Health, 12 May 2021, (doi: https://doi.org/10.1080/09638237 .2021.1922636)

Ahorsu, Daniel Kwasi - Lin, Chung-Ying - Imani, Vida - Saffari, Mohsen - Griffiths, Mark D. - Pakpour, Amir H., "The Fear of COVID-19 Scale: Development and Initial Validation", International Journal of Mental Health and Addiction, 2020, (https://doi.org/10.1007/s11469-020-00270-8)

Altundağ, Yunus, "Erken Dönem Covid-19 Pandemisinde Covid-19 Korkusu ve Psikolojik Dayanıklılık”, EKEV Akademi Dergisi, cilt 25, say1 85, 2021.

Anderson, Suzanne M., Developing Resilience-The Danger and Opportunity of COVID-19 for International School Educators (Part 2), https://www.restorativecommunityconcepts.com/uploads/2/8/1/0/2810779/coping_-_article_3_ covid-19_final.pdf. 19 March 2020.

Arslan, Filiz - Ayas, Tuncay, "Din ve Psikoloji Eğitimi Alan Öğrencilerin Psikolojik Sağlamlık ve Affedicilik Düzeylerinin Çeşitli Değişkenler Açısından Incelenmesi”, Sakarya Üniversitesi Ĕgitim Fakültesi Dergisi, sayı 38, Aralık 2019.

Aydın, Betül - İmamoğlu, Seval, "Stresle Başa Çıkma Becerisi Geliştirmeye Yönelik Grup Çalışması”, Marmara Üniversitesi Atatürk Eğitim Fakültesi Eğitim Bilimleri Dergisi, sayı 14, Aralık 2001..

Ayten, Ali - Yıldız, Refik, "Dindarlık, Hayat Memnuniyeti İlişkisinde Dinî Başa Çıkmanın Rolü Nedir? Emekliler Üzerine Bir Araştırma", Dinbilimleri Journal, cilt 16, say1 1, 2016.

Bakioğlu, Fuad - Korkmaz, Ozan - Ercan, Hülya, "Fear of COVID-19 and Positivity: Mediating Role of Intolerance of Uncertainty, Depression, Anxiety, and Stress", International Journal of Mental Health and Addiction, May1s 2020, (https://doi.org/10.1007/s11469-020-00331-y )

Baron, Reuben M. - Kenny, David A., "The Moderator-Mediator Variable Distinction in Social Psychological Research: Conceptual, Strategic, and Statistical Considerations", Journal of Personality and Social Psychology, vol. 51, no. 6, 1986. 
Baykal, Elif, "COVID-19 Bağlamında Psikolojik Dayanıklılık, Kaygı ve Yaşam Doyum İlişkisi”, International Journal of Social and Economic Sciences, cilt 10, say1 2, 2020.

Beasley, Margaret - Thompson, Ted - Davidson, John, "Resilience in Response to Life Stress: The Effects of Coping Style and Cognitive Hardiness", Personality and Individual Differences, vol. 34, 2003, (https://doi.org/10.1016/ S0191-8869(02)00027-2 )

Bentzen, Jeanet Sinding, "Acts of God? Religiosity and Natural Disasters Across Subnational World Districts" The Economic Journal, vol. 129, no. 622, 2019, (https://doi.org/10.1093/ej/uez008) , "In Crisis, We Pray: Religiosity and the COVID-19 Pandemic", CEPR Discussion Papers, 2020.

Billings, Andrew G. - Moos, Rudolf H., "Coping, Stress and Social Resources Among Adults with Unipolar Depression", Journal of Personality and Social Psychology, vol. 46, no. 4, 1984, (https://psycnet.apa.org/doi/10.1037/00223514.46.4.877 )

Bonanno, George A., "Loss, Trauma, and Human Resilience: Have We Underestimated the Human Capacity to Thrive After Extremely Aversive Events?", American Psychologist, vol. 59, no. 1, 2004, (https://psycnet.apa.org/ doi/10.1037/0003-066X.59.1.20)

Bonanno, George A. - Wortman, Camille B. - Nesse, Randolph M., "Prospective Patterns of Resilience and Maladjustment During Widowhood", Psychology and Aging, vol. 19, 2004, (https://psycnet.apa.org/doi/10.1037/08827974.19.2.260)

Bonanno, George A. - Kennedy, Paul - Galatzer-Levy, Isaac R. - Lude, Peter - Elfström, Mangus L., "Trajectories of Resilience, Depression, and Anxiety Following Spinal Cord Injury", Rehabilitation Psychology, vol. 57, 2012, (https:// psycnet.apa.org/doi/10.1037/a0029256 )

Boysan, Murat, "Validity of the Coping Inventory for Stressful Situations-Short Form (CISS-21) in A Non-Clinical Turkish Sample", Düşünen Adam-The Journal of Psychiatry and Neurological Sciences, cilt 25, say1 2, 2012, (https://dx.doi.org/10.5350/DAJPN2012250201)

Brooks, Samantha K. - Webster, Rebecca K. - Smith, Louise E. - Woodland, Lisa - Wessely, Simon - Greenberg, Neil - Rubin, Gideon James, "The Psychological Impact of Quarantine and How to Reduce It: Rapid Review of The Evi- 
dence", The Lancet, vol. 395, no. 10227, March 2020, (https://doi.org/10.1016/ S0140-6736(20)30460-8)

Brousse, Georges - Arnaud, Benjamin - Roger, Jordane Durand - Geneste, Julie - Bourguet, Delphine - Zaplana, Frederic - Blanc, Olivier - Jeannot, Schmid Jehel, Louis, "Management of Traumatic Events: Influence of Emotion-Centered Coping Strategies on The Occurrence of Dissociation and Post-Traumatic Stress Disorder", Neuropsychiatric Disease and Treatment, vol. 7, 2011, (https://dx.doi. org/10.2147\%2FNDT.S17130)

Büyüköztürk, Şener, Sosyal Bilimler İçin Veri Analizi El Kitabl, Ankara, Pegem Akademi, 2012.

Cal, Silvia Fernanda - de Sá, Lis Ribeiro - Glustak, Maria Eugenia - Santiago, Mittermayer Barreto, "Resilience in Chronic Diseases: A Systematic Review", Cogent Psychology, vol. 2, no. 1, April 2015, 1024928, (https://doi.org/10 $.1080 / 23311908.2015 .1024928)$

Cao, Wenjun - Fang, Ziwei - Hou, Guoqiang - Han, Mei - Xu, Xinrong Dong, Jiaxin - Zheng, Jianzhong, "The Psychological Impact of the COVID-19 Epidemic on College Students in China", Psychiatry Research, vol. 287, May 2020, 112934, (https://doi.org/10.1016/j.psychres.2020.112934)

Carver, Charles. S. - Scheier, Michael F. - Weintraub, Jagdish. K., "Assessing Coping Strategies: A Theoretically Based Approach", Journal of Personality and Social Psychology, vol. 56, 1989, (https://psycnet.apa.org/doi/10.1037/00223514.56.2.267)

Connor, Kathryn M. - Davidson, Jonathan R. T. - Lee, Li-Ching, "Spirituality, Resilience, and Anger in Survivors of Violent Trauma: A Community Survey", Journal of Traumatic Stress, vol. 16, 2003.

Connor, Kathryn M. - Zhang, Wei, "Recent Advances in The Understanding and Treatment of Anxiety Disorders. Resilience: Determinants, Measurement, and Treatment Responsiveness", CNS Spectrums, 11, 2006, (https://doi. org/10.1017/S1092852900025797)

Coşkun, Recai - Altunışık, Remzi - Yıldırım, Engin, Sosyal bilimlerde araştırma yöntemleri SPSS uygulamal, İstanbul, Sakarya Yayınc1lı, 2017.

Creswell, John W., Araştırma deseni: Nitel, nicel ve karma yöntem yaklaşımları, çev. ed. Selçuk Beşir Demir, Ankara, Eğiten Kitap, 2014.

Çetin, Cemile - Anuk, Özlem, "COVID-19 Pandemi Sürecinde Yalnızlık ve Psikolojik Dayanıklılık: Bir Kamu Üniversitesi Öğrencileri Örneklemi”, Avrasya Sosyal ve Ekonomi Araştırmaları Dergisi, cilt 7, sayı 5, 2020. 
Dalkılıç, Mehmet - Temel, Veysel, "Ergenlerde Öfke İfade Tarzları”, V. International Congress on Natural and Health Sciences (ICNHS-2019), 2019.

Davydov, Dmitry M. - Stewart, Robert - Ritchie, Karen - Chaudieu, Isabelle, "Resilience and mental health", Clinical Psychology Review, vol. 30, 2010, (https://doi.org/10.1016/j.cpr.2010.03.003)

Djalante, Riyanti - Lassa, Jonatan - Setiamarga, Davin - Sudjatma, Aruminingsih - Indrawan, Mochamad - Haryanto, Budi - Mahfud, Choirul - Sinapoy, Muhammad Sabaruddin - Djalante, Susanti - Rafliana, Irina - Gunawan, Lali Adu - Surtiari, Gusti Ayu, Ketut - Warsilah, Henny, "Review and Analysis of Current Responses To COVID-19 In Indonesia: Period of January to March 2020", Progress in Disaster Science, vol. 6, 2020, 100091, (https://doi.org/10.1016/j.pdisas.2020.100091)

Doğan, Tayfun, "Kısa Psikolojik Sağlamlık Ölçeği’nin Türkçe Uyarlaması: Geçerlik ve Güvenirlik Çalışması", The Journal of Happiness \& Well-Being, cilt 3, sayı 1, 2015.

Duan, Li - Zhu, Gang, "Psychological Interventions for People Affected by the COVID-19 Epidemic", The Lancet Psychiatry, vol. 7, no. 4, 2020.

Ekşi, Halil, "Başaçıkma, Dinî Başaçıkma ve Ruh Sağlığı Arasındaki İlişki Üzerine Bir Araştırma: Eğitim, Ilâhiyat ve Mühendislik Fakültesi Öğrencilerinin Karşılaştırılması", (Yayımlanmamış Doktora Tezi), Uludağ Üniversitesi, Bursa, 2001.

Endler, Normen S. - Parker, James D. A., Coping Inventory for Stressful Situations (CISS): Manual, Toronto, Multi-Health Systems Incorporated, 1990.

, "State and Trait Anxiety, Depression and Coping Styles", Australian Journal of Psychology, vol. 42, no. 2, 1990.

Erdoğdu, Yeşim - Koçoğlu, Filiz - Sevim, Celil, "COVID-19 Pandemisi Sürecinde Anksiyete ile Umutsuzluk Düzeylerinin Psikososyal ve Demografik Değişkenlere Göre İncelenmesi”, Klinik Psikiyatri Dergisi, vol. 23, 2020, (doi: 10.5505/kpd.2020.35403)

Eryücel, Sema, "Dini Yönelim ve Başa Çıkma”, Turkish Studies, cilt 13, sayı 2, 2018.

Folkman, Susan - Moskowitz, Judith Tedlie, "Coping: Pitfalls and Promise", Annual Review of Psychology, vol. 55, 2004, (https://doi.org/10.1146/annurev. psych.55.090902.141456)

Frankl, Victor Emile, Duyulmayan Anlam Çığglı̆̆l, çev. Selçuk Budak, Ankara, Öteki Yayınevi, 1994. 
Gao, Wenbin - Chen, Zhiyan - Wang, Yiniu, "Analysis on The Influence and Change Trend of Public Mentality During Sars Epidemic", Chinese Mental Health Journal, vol. 17, no. 9, 2003.

Garfin, Dana Rose - Silver, Roxane Cohen - Holman, E. Alison, "The Novel Coronavirus (COVID-2019) Outbreak: Amplification of Public Health Consequences by Media Exposure", Health Psychology, vol. 39, no. 5, 2020, (http:// dx.doi.org/10.1037/hea0000875)

Gerhold, Lars, COVID-19: Risk perception and coping strategies, March 2020, (https://doi.org/10.31234/osf.io/xmpk4)

Gilbar, Ora - HevroniI, Avi, “Counterfactuals, Coping Strategies and Psychological Distress Among Breast Cancer Patients" Anxiety, Stress, and Coping, vol. 20, no. 4, 2007, (https://doi.org/10.1080/10615800701384439)

Goyal, Kapil - Chauhan, Poonam - Chhikara, Komal - Gupta, Parakriti - Singh, Mini P., "Fear of COVID 2019: First Suicidal Case in India", Asian Journal of Psychiatry, vol. 49, 2020, e101989, (https://dx.doi.org/10.1016\%2Fj. ajp.2020.101989)

Gül, Ahmet - Gül, Hesna - Erberk-Özen, Nurper - Battal, Salih, "Major Depresyon Hastalarında Çocukluk Çağı Travmaları ve Başa Çıkma Tutumlarının Cinsiyete Özgü Farkl1l1kları", Türk Psikiyatri Dergisi, cilt 28, say1 4, 2017, (doi: 10.5080/u18193)

Haktanır, Abdulkadir - Seki, Tolga - Dilmaç, Bülent, "Adaptation and Evaluation of Turkish Version of The Fear of COVID-19 Scale", Death Studies, 29 May 2020, (doi: https://doi.org/10.1080/07481187.2020.1773026)

Heijmans, Monique, “The Role of Patients' Illness Representations in Coping and Functioning with Addison's Disease", British Journal of Health Psychology, vol. 4, no. 2, 1999.

Herman, Judith Lewis, "Trauma and Recovery", The Aftermath of Violence-From Domestic Abuse to Political Terror (Chapter 3), Hachette, UK, 2015.

Higgins, June E. - Endler, Norman S., "Coping, Life Stress, and Psychological and Somatic Distress", European Journal of Personality, vol. 9, 1995, (https:// doi.org/10.1002/per.2410090403)

Ho, Cyrus. S. H. - Chee, Cornelia Y. I. - Ho, Roger. C. M., "Mental Health Strategies to Combat the Psychological Impact Of COVID-19 Beyond Paranoia and Panic", Annnals Academy Medicine, Singapore, vol. 49, no. 1, 2020. 
Holahan, Charles J. - Moos, Rudolf H. - Holahan, Carole K. - Brennan, Penny L. - Schutte, Kathleen K., "Stress Generation, Avoidance Coping, and Depressive Symptoms: A 10-Year Model”, Journal of Consulting and Clinical Psychology, vol. 73, no. 4, 2005, (https://psycnet.apa.org/doi/10.1037/0022006X.73.4.658)

Horesh, Danny - Brown, Adam. D., "Traumatic Stress in The Age Of COVID-19: A Call to Close Critical Gaps and Adapt to New Realities", Psychological Trauma: Theory, Research, Practice, and Policy, vol. 12, no. 4, 2020.

Huang, Long - Lei, Wansheng - Xu, Fuming - Liu, Hairong - Yu, Liang, "Emotional Responses and Coping Strategies in Nurses And Nursing Students During COVID-19 Outbreak: A Comparative Study", PLoS ONE, vol. 15, no. 8, 2020, e0237303, (https://doi.org/10.1371/journal. pone.0237303)

Huynh, Toan Luu Duc, "The More I Fear About COVID-19, The More I Wear Medical Masks: A Survey on Risk Perception and Medical Masks Uses", medRxiv, 2020, (https://doi.org/10.1101/2020.03.26.20044388)

Hvidtjørn, Dorte - Hjelmborg, Jacob - Skytthe, Axel - Christensen, Kaare - Hvidt, Niels Christian, "Religiousness and Religious Coping In A Secular Society: The Gender Perspective", Journal of Religion and Health, vol. 53, no. 5, 2014, (https://dx.doi.org/10.1007\%2Fs10943-013-9724-z)

Inchausti, Felix - MacBeth, Angus - Hasson-Ohayon, Ilanit - Dimaggio, Giancarlo, "Psychological Intervention and COVID-19: What We Know So Far and What We Can Do", Journal of Contemporary Psychotherapy, 2020, (https://dx. doi.org/10.1007\%2Fs10879-020-09460-w)

Istratii, R., Restricting Religious Practice in The Era Of COVID-19: A De-Westernised Perspective on Religious Freedom with Reference to The Case of Greece, 15 April 2020, (https://politicaltheology.com/restricting-religious-practice-in-the-era-of-covid-19-a-de-westernised-perspective-on-religious-freedomwith-reference-to-the-case-of-greece/)

Karagöz, Yalçın, SPSS 23 ve AMOS 23 Uygulamalı Istatistiksel Analizler, Ankara, Nobel Akademik Yayınc1lık, 2016.

Karaırmak, Özlem, "Psikolojik Sağlamlık, Risk Faktörleri ve Koruyucu Faktörler”, Türk Psikolojik Danışma ve Rehberlik Dergisi, cilt 3, sayı 26, 2006.

Karaırmak, Özlem - Siviş-Çetinkaya, Rahşan, "Benlik Saygısının ve Denetim Odağının Psikolojik Sağlamlık Üzerine Etkisi: Duyguların Aracı Rolü”, Türk Psikolojik Danışma ve Rehberlik Dergisi, cilt 4, sayı 35, 2011. 
Karakaş, Ahmet Canan - Koç, Mustafa, "Stresle Başa Çıkma ve Dini Başa Çıkma Yöntemleri Arasındaki İlişkinin Çeşitli Değişkenler Açısından İncelenmesi”, Itobiad: Journal of the Human \& Social Science Researches, cilt 3, say1 3, 2014, (https://doi.org/10.15869/itobiad.88954)

Karaman, Mehmet Akif - Kumaran, Ajitha Chandrika - Haktanir Abdulkadir - Lenz, Stephen, "Predictors of Counselor-in-Training Students' General Self-Efficacy", Akdeniz Eğitim Araştırmaları Dergisi, cilt 12, sayı 25, (doi:10.29329/ mjer.2018.153.8.)

Kim, Hyun-Chung - Yoo, So-Young - Lee, Bun-Hee - Lee, So Hee - Shin, Hyoung-Shik, "Psychiatric Findings in Suspected and Confirmed Middle East Respiratory Syndrome Patients Quarantined in Hospital: A Retrospective Chart Analysis", Psychiatry investigation, vol. 15, no. 4, 2018, (https://dx.doi. org/10.30773\%2Fpi.2017.10.25.1)

Kim, Sung-Wan - Su, Kuan-Pin, "Using Psychoneuroimmunity Against COVID-19", Brain, Behavior, and Immunity, 2020, (https://doi.org/10.1016/j. bbi.2020.03.025)

Knibb, Rebecca C. - Horton, S. L., "Can Illness Perceptions and Coping Predict Psychological Distress Amongst Allergy Sufferers?", British Journal of Health Psychology, vol. 13, no. 1, 2008, (https://doi.org/10.1348/135910706X173278)

Kobasa, Suzanne. C. - Puccetti, Mark. C., "Personality and Social Resources in Stress Resistance", Journal of Personality and Social Psychology, vol. 45, no. 4, 1983.

Konkan, Ramazan - Erkuş, Gizem Hanzade - Güçlü, Oya - Şenormanc1, Ömer - Aydın, Erkan - Ülgen, Mine Cansu - Sungur, Mehmet Zihni, "İntihar Girişiminde Bulunan Kişilerde Başa Çıkma Tutumları", Archives of Neuropsychiatry/Noropsikiatri Arsivi, cilt 51, say1 1, 2014, (doi: 10.4274/npa.y6578)

Kula, Naci, “İstenmedik ve Beklenmedik Olaylarla Karş1laşan Bireylere Yönelik Moral ve Manevî Desteğin Önemi (Deprem ve Bedensel Engellilik Örneği)", Din Bilimleri Akademik Araştırma Dergisi, cilt 6, sayı 3, 2006.

Ladikli, Nefise - Bahadır, Erdi - Yumuşak, Fatıma Nurefşan - Akkuzu, Hüdanur - Karaman, Gülşen - Türkkan, Zeynep, “Kovid-19 Korkusu Ölçeği'nin Türkçe Güvenirlik ve Geçerlik Çalışması”, International Journal of Social Science, cilt 3, say1 2, 2020.

Lazarus, Richard S., "Theory-based Stress Measurement", Psychological Inquiry, vol 1, no. 1, 1990, (https://doi.org/10.1207/s15327965pli0101_1) 
, "Coping theory and research: Past, present, and future", Psychosomatic Medicine, vol. 55, 1993.

Lazarus, Richard S. - Folkman, Susan, Stress, appraisal and coping, New York, Pringer, 1984.

Lee, Hei-Sung - Brown, Stephen L. - Mitchell, Mary M. - Schiraldi, Gleen. R., "Correlates of Resilience in The Face of Adversity for Korean Women Immigrating to The U.S.”, Journal of Immigrant and Minority Health, vol. 10, 2008, (https://doi.org/10.1007/s10903-007-9104-4)

Lee, Sherman A. - Mathis, Amanda A. - Jobe, Mary C. - Pappalardo, Emily. A., "Clinically Significant Fear and Anxiety Of COVID-19: A Psychometric Examination of The Coronavirus Anxiety Scale", Psychiatry Research, 2020, 113112, (https://doi.org/10.1016/j.psychres.2020.113112)

Lewis, Christopher Alan - Maltby, John - Day, Liz, "Religious Orientation, Religious Coping and Happiness Among UK Adults", Personality and Individual Differences, vol. 38, no. 5, 2005, (https://doi.org/10.1016/j.paid.2004.08.002)

Li, Sijia - Wang, Yilin - Xue, Jia - Zhao, Nan - Zhu, Tingshao, “The Impact Of COVID-19 Epidemic Declaration on Psychological Consequences: A Study on Active WEIBO Users", International Journal of Environmental Research and Public Health, vol. 17, no. 6, 2020, (https://doi.org/10.3390/ijerph17062032)

Li, Juan - Wang, Ting - Wang, Jinwen, "Research on The Relationship Between College Students' Psychological Resilience and Coping Style Under the Perspective Of Positive Psychology", Advances in Social Science, Education and Humanities Research, vol. 321, 2019, (https://dx.doi.org/10.2991/ mmetss-19.2019.49)

Liu, Shuai - Yang, Lulu - Zhang, Chenxi - Xiang, Yu-Tao - Liu, Zhongchun. $\mathrm{Hu}$, Shaouha - Zhang, Bin, "Online Mental Health Services in China During The COVID-19 Outbreak", The Lancet Psychiatry, vol. 7, no. 4, 2020, (https://doi. org/10.1016/S2215-0366(20)30077-8)

Maltby, John - Day, Liza, "Religious Orientation, Religious Coping and Appraisals of Stress: Assessing Primary Appraisal Factors in The Relationship Between Religiosity and Psychological Well-Being”, Personality and Individual Differences vol. 34, 2003.

Mamun, Mohammed A. - Griffiths, Mark D., "First COVID-19 Suicide Case in Bangladesh Due to Fear Of COVID-19 And Xenophobia: Possible Suicide Prevention Strategies", Asian Journal of Psychiatry, vol. 51, 2020, 102073, (https:// dx.doi.org/10.1016\%2Fj.ajp.2020.102073) 
Masten, Ann. S. - Coastworth, J. Douglas, "The Development of Competence in Favorable and Unfavorable Environments: Lessons from Research on Successful Children", American Psychologist, vol. 53, no. 2, 1998, (https://psycnet. apa.org/doi/10.1037/0003-066X.53.2.205)

Matud, M. Pilar, "Gender differences in stress and coping styles", Personality and Individual Differences, vol. 37, no. 7, 2004, (https://doi.org/10.1016/j. paid.2004.01.010)

McIntire, Laura - Duncan, Renae, “Associations Among Religious Coping, Daily Hassles, and Resilience", Archive for the Psychology of Religion vol. 35, no. 1, 2013.

Mertens, Gaetan - Gerritsen, Lotte - Duijndam, Stefanie - Salemink, Elske - Engelhard, Iris M., "Fear of The Coronavirus (COVID-19): Predictors in An Online Study Conducted in March 2020", Journal of Anxiety Disorders, 2020, 102258, (https://doi.org/10.1016/j.janxdis.2020.102258)

Montemurro, Nicola, "The Emotional Impact of COVID-19: From Medical Staff to Common People", Brain, Behavior, and Immunity, 2020, (https://dx.doi. org/10.1016\%2Fj.bbi.2020.03.032)

Morens, David M. - Fauci, Anthoney. S., "Emerging Infectious Diseases: Threats to Human Health and Global Stability", PLoS Pathogens, vol. 9, no. 7, 2013.

Morris, Charles G., Psikolojiyi anlamak (Psikolojiye giriş), çev. H. Belgin Ayvaşık - Melike Sayıl, Ankara, Türk Psikologlar Derneği Yayınları, 2002.

Ozbay, Fatih - Johnson, Douglas C. - Dimoulas, Eleni - Morgan, C. A. - Charney, Dennis - Southwick, Stewan, "Social support and resilience to stress: from neurobiology to clinical practice", Psychiatry (Edgmont (Pa.: Township)), vol. 4, no. 5, 2007.

Qian, Mengcen - Wu, Qianhui - Wu, Peng - Hou, Zhiyuan - Liang, Yuxia - Cowling, Benjamin J. - Yu, Hongjie, "Psychological responses, behavioral changes and public perceptions during the early phase of the COVID-19 outbreak in China: A population-based cross-sectional survey.", medRxiv, 2020, (doi: 10.1101/2020.02.18.20024448)

Qiu, Jianyin - Shen, Bin - Zhao, Min - Wang, Zhen - Xie, Bin - Xu, Yifeng, "A Nationwide Survey of Psychological Distress Among Chinese People in the COVID-19 Epidemic: İmplications And Policy Recommendations", General psychiatry, vol. 33, no. 2, 2020, e100213corr1, (https://dx.doi.org/10.1136\%2Fgpsych-2020-100213) 
Pakpour, Amir. H. - Griffiths, Mark D., "The fear of COVID-19 and its Role in Preventive Behaviors", Journal of Concurrent Disorders, vol. 2, no. 1, 2020.

Pappas, Georgios, - Kiriaze, Ismene J. - Giannakis, P. - Falagas, Matthew E., "Psychosocial Consequences of Infectious Diseases", Clinical Microbiology and Infection, vol. 15, no. 8, 2009, (https://doi.org/10.1111/j.14690691.2009.02947.x)

Pargament, Kenneth. I., "The psychology of religion and coping: Theory, research, practice”, New York, The Guilford Press, 1997.

Pargament, Kenneth. I. - Falb, Melissa D. - Ano, Gene G. - Wachholtz, Amy, B., "The Religious Dimension of Coping: Advances in Theory, Research, And Practice", Handbook of The Psychology of Religion and Spirituality, ed. Raymond F. Paloutzian - Crystal L. Park, The Guilford Press, 2005.

Pargament, Kenneth. I. - Brant, Curtis R., "Religion and coping", Handbook of religion and mental health, ed. Harold G. Koenig, San Diego, Academic Press, 1998.

Pargament, Kenneth. I. - Smith, Bruce W. - Koenig, Herold. G. - Perez, Lisa, "Patterns of Positive and Negative Religious Coping with Major Life Stressors", Journal for the Scientific Study of Religion, 1998. (https://doi. org/10.2307/1388152)

Pargament, Kenneth. I., Koenig, Herold G. - Perez, Lisa, "The Many Methods of Religious Coping: Development and Initial Validation of The RCOPE", Journal of Clinical Psychology, vol. 56, no. 4, 2000, (https://doi.org/10.1002/ (SICI)1097-4679(200004)56:4\%3C519::AID-JCLP6\%3E3.0.CO;2-1)

Pargament, Kenneth. I. - Park, Crystal L., "Merely A Defense? The Variety of Religious Means and Ends", Journal of Social Issues, vol. 51, 1995, (https://doi. $\operatorname{org} / 10.1111 / \mathrm{j} .1540-4560.1995 . t b 01321 . x)$

Pargament, Kenneth. I. - Tarakeshwar, Nalini - Ellison, Christopher. G. Wulf, Keith M., "Religious Coping Among the Religious: The Relationships Between Religious Coping and Well-Being in A National Sample of Presbyterian Clergy, Elders, And Members", Journal for the Scientific Study of Religion, vol. 40, 2001, (https://doi.org/10.1111/0021-8294.00073)

Pargament, Kenneth. I. - Zinnbauer, Brian J. - Scott, Allie B. - Butter, Eric M. - Zerowin, Jill - Stanik, Patricia, "Red Flags and Religious Coping: Identifying Some Religious Warning Signs Among People in Crisis", Journal of Clinical Psychology, vol. 59, no. 12, 2003. 
Pirutinsky, Steven - Cherniak, Aaron D. - Rosmarin, David H, "COVID-19, Mental Health, and Religious Coping Among American Orthodox Jews", Journal of Religion of the Health, vol. 59, 2020, (doi: https://doi.org/10.1007/s10943020-01070-z)

Plutchik, Robert, "A General Psychoevolutionary Theory of Emotion", Emotion: Theory, Research, and Experience: Vol 1. Theories of Emotion, eds. Robert Plutchik - Hanry Kellerman, New York, Academic, 1980.

Polizzi, Craig - Lynn, Steven Jay - Perry, Andrew, "Stress and Coping in The Time Of COVID-19: Pathways to Resilience and Recovery", Clinical Neuropsychiatry, vol. 17, no. 2, 2020.

Reardon, Sara, "Ebola's Mental-Health Wounds Linger in Africa",Nature News, vol. 519, no. 7541, 2015.

Remuzzi, Andrea - Remuzzi, Giuseppe, "COVID-19 and Italy: What Next?", The Lancet, vol. 395, 2020.

Rutter, Michael - Quinton, David, "Long-Term Follow-Up of Women Institutionalized in Childhood: Factors Promoting Good Functioning in Adult Life", British Journal of Developmental Psychology, vol. 18, 1984, (https://doi. org/10.1111/j.2044-835X.1984.tb00925.x)

Scali, Jacqueline - Gandubert, Catherine - Ritchie, Karen - Soulier, Maryvonne - Ancelin, Marie-Laure - Chaudieu, Isabelle, "Measuring Resilience in Adult Women Using The 10-Items Connordavidson Resilience Scale (CD-RISC). Role of Trauma Exposure and Anxiety Disorders", PloS One, vol. 7, 2012, (https://doi. org/10.1371/journal.pone.0039879)

Schnider, Kimberly R. - Elhai Jon D. - Gray, Matt J., "Coping Style Use Predicts Posttraumatic Stress and Complicated Grief Symptom Severity Among College Students Reporting A Traumatic Loss", Journal of Counseling Psychology, vol. 54, no. 3, 2007, (https://doi.org/10.1037/0022-0167.54.3.344)

Seligman, Martin E. P. - Csikzentmihalyi, Mihaly, "Positive Psychology: An Introduction”, American Psychologist, vol. 55, 2000.

Seltzer, Marsha Mailick - Greenberg, Jan S. - Krauss, Marty Wyngaarden, “A Comparison of Coping Strategies of Aging Mothers of Adults with Mental Illness or Mental Retardation", Psychology and Aging, vol. 10, no. 1, 1995, (https:// psycnet.apa.org/doi/10.1037/0882-7974.10.1.64)

Sexton, Minden B. - Byrd Michelle R. - von Kluge Silvia, "Measuring Resilience in Women Experiencing Infertility Using The CD-RISC: Exam- 
ining Infertility-Related Stress, General Distress, And Coping Styles", Journal of Psychiatric Research, vol. 44, 2010, (https://doi.org/10.1016/j.jpsychires.2009.06.007)

Shigemura, Jun - Ursano, Robert J. - Morganstein, Joshua C. - Kurosawa, Mie - Benedek, David M., "Public Responses to The Novel 2019 Coronavirus (2019-Ncov) In Japan: Mental Health Consequences and Target Populations", Psychiatry and Clinical Neurosciences, 2020, (doi: 10.1111/pcn.12988), [Epub ahead of print]

Shin, Lisa M. - Liberzon, Israel, "The Neurocircuitry of Fear, Stress, and Anxiety Disorders", Neuropsychopharmacology, vol. 35, 2010.

Simione, Luca - Gnagnarella, Camilla, "Differences Between Health Workers and General Population in Risk Perception, Behaviors, and Psychological Distress Related to COVID-19 Spread in Italy", Frontiers in Psychology, vol. 11, 2020, (https://doi.org/10.3389/fpsyg.2020.02166)

Skalisky, Jordan - Wanner, Scott - Howe, Bradford - Mauseth, Kira, "Religious Coping, Resilience, and İnvoluntary Displacement: A Mixed-Methods Analysis of The Experience of Syrian and Palestinian Refugees in Jordan", Psychology of Religion and Spirituality, Advance Online Publication, 2020, (https:// doi.org/10.1037/re10000390)

Smith, Martin M. - Saklofske, Donald H. - Keefer, Kateryna V. - Tremblay, Paul F., "Coping Strategies and Psychological Outcomes: The Moderating Effects of Personal Resiliency", The Journal of Psychology, vol. 150, no. 3, 2016, (https://doi.org/10.1080/00223980.2015.1036828)

Sobel, Michael E., "Asymptotic Confidence Intervals for Indirect Effects in Structural Equation Models", Sociological Methodology, ed. S. Leinhardt, Washington DC, American Sociological Association, 1982.

Soderstrom, Mike - Dolbier, Christyn - Leiferman, Jenn - Steinhardt, Mary, "The Relationship of Hardiness, Coping Strategies, and Perceived Stress to Symptoms Of Illness", Journal of Behavioral Medicine, vol. 23, 2000.

Spulber, Diana, "Coping and Resilience in Life-Long Learning and Ageing: New Challenges", Geopolitical, Social Security and Freedom Journal, vol. 2, no. 1, 2019, (Doi: 10.2478/gssfj-2019-0009)

Stankovska, Gordana - Memed1, Imran - Dimitrovski, Dimitar, "Coronavirus COVID-19 Disease, Mental Health, and Psychosocial Support", Society Register, vol. 4, no. 2, 2020, (https://doi.org/10.14746/sr.2020.4.2.03) 
Stilley, Carol S. - DiMartini, Andrea F. - de Vera, Michael E. - Flynn, William B. - King, Jennifer - Sereika, Susan - Tarter, Ralph E. - Dew, Mary Amanda - Rathnamala, Geetha, "Individual and Environmental Correlates and Predictors of Early Adherence and Outcomes After Liver Transplantation", Progress in Transplantation, vol. 20, no. 1, 2010, (https://doi.org/10.1177\%2F152692481002000110)

Sun, Luna - Sun, Zhuoer - Wu, Lili - Zhu, Zhenwen - Zhang, Fan - Shang, Zhilei - Jia, Yanpu - Gu, Jingwen - Zhou, Yaoguang - Wang, Yan - Liu, Nianqi - Liu, Weizhi, "Prevalence and Risk Factors of Acute Posttraumatic Stress Symptoms During The COVID-19 Outbreak in Wuhan, China", medRxiv, 2020, (https://doi.org/10.1101/2020.03.06.20032425)

Şeker, Tuba - Yıldırım, Yavuz Tansoy, "Çalışanlarda Tükenmişlik ve Sanal Kaytarma Davranışları Arasındaki İlişkinin İncelenmesi: Enerji Sektöründe Bir Araştırma", Uygulamalı Ekonomi ve Sosyal Bilimler Dergisi, cilt 1, sayı 2, 2019.

Şentepe, Ayşe, "Yaşlılık Döneminde Dini Başaçıkma", İnsan ve Toplum Bilimleri Araştırmaları Dergisi, cilt 4, sayı 1, 2015.

Tabachnick, Barbara G. - Fidell, Linda S., "Components and Factor Analysis", Using Multivariate Statistics, vol. 4, 2001.

Taylor, Shelly. E. - Peplau Letitia. A. - Sears, David O., Sosyal psikoloji, çev. Ali Dönmez, Ankara, İmge Kitabevi, 2010.

Topalidou, Anastasia - Thomson, Gill - Downe, Soo, "COVID-19 And Maternal Mental Health: Are We Getting the Balance Right?”, medRxiv, 2020, (https:// doi.org/10.1101/2020.03.30.20047969)

Tugade, Michele M. - Frederickson, Barbara L., "Resilient Individuals Use Positive Emotions to Bounce Back from Negative Emotional Experiences", Journal of Personality and Social Psychology, vol. 86, no. 2, 2004, (https://psycnet. apa.org/doi/10.1037/0022-3514.86.2.320)

Tunç-Aksan, Aygül, - Gizir, Cem Ali, "Meme Kanseri Tanısı Almış Kadınların Hastalık Temsilleri ve Başa Çıkma Tarzları ile Kaygı ve Depresyon Düzeyleri Arasındaki İlişkilerin İncelenmesi”, Turkish Psychological Counseling and Guidance Journal, cilt 9, say1 54, 2019.

Tutal, Varol - Efe, Mehmet, "Bireylerin Psikolojik Sağlamlık ve Covid-19 Korkularının Çeşitli Değişkenlere Göre İncelenmesi”, Journal of International Social Research, vol. 13, no. 74, 2020.

Yıldız-Türker, Nesrin, "Yetişkinlerde Dindarlık ve Psikolojik Sağlamlık Ilişkisi Üzerine Bir Araştırma”, (Yayımlanmamış Yüksek Lisans Tezi), Uludağ Üniversitesi, Bursa, 2018. 
Ungar, Michael, "Resilience Across Cultures", British Journal of Social Work, vol. 38, no. 2, 2008, (https://doi.org/10.1093/bjsw/bcl343)

, "Resilience, Trauma, Context, and Culture", Trauma, Violence, \& Abuse, vol. 14, no. 3, 2013, (https://doi.org/10.1177\%2F1524838013487805)

Uysal, Veysel - Kaya-Göktepe, Ayşe - Karagöz, Sema - İlerisoy, Melike, "Dinî Başa Çıkma ile Umut, Hayat Memnuniyeti ve Psikolojik Sağlamlık Arasındaki Etkileşim Üzerine Bir Araştırma”, Marmara Üniversitesi İlâhiyat Fakültesi Dergisi, cilt 52, say1 52, 2017, (doi: https://doi.org/10.15370/maruifd.333535)

Van Bavel, Jay. J. - Baicker, Katherine - Boggio, Paulo. S. - Capraro, Valerio - Cichocka, Aleksandra - Cikara, Mina - ... - Willer, Robb, "Using Social and Behavioural Science to Support Covid-19 Pandemic Response", Nature Human Behavior, vol. 4, 2020, (https://doi.org/10.1038/s41562-020-0884-z)

Yanyu, Jiang - Xi, Yang - Huiqi, Tong - Bangjiang, Fang - Bin, Li - Yabin, Gong - Xin, Ma - Junhua, Zheng - Zhitao, Yang - Xiaoyun, Chen - Changsheng, Dong - Yanmei, Zhang - Jianguang, Xu - Lijun, Jia, "Meditation-Based Interventions Might Be Helpful for Coping with Coronavirus Disease 2019 (COVID-19)", 2020, (https://doi.org/10.31219/osf.io/f3xzq)

Yapıcı, Asım, Ruh Sağlı̆̆ı ve Din Psiko-Sosyal Uyum ve Dindarlı, Adana, Karahan Kitabevi, 2007.

Yu, Hua - Li, Mingli - Li, Zhxiong - Xiang, Weiyi - Yuan, Yiwen - Liu, Yaya Li, Zhe - Xiong, Zhenzhen, "Coping Style, Social Support, and Psychological Distress in The General Chinese Population in The Early Stages of the COVID-2019 Epidemic", April 2020, (https://doi.org/10.21203/rs.3.rs-20397/v2)

Wang, Cuiyan - Pan, Riyu - Wan, Xiaoyang - Tan, Yilin - Xu, Linkang - Ho, Cyrus S. - Ho, Roger C., "Immediate Psychological Responses and Associated Factors During the Initial Stage of the 2019 Coronavirus Disease (COVID-19) Epidemic Among the General Population in China", International Journal of Environmental Research and Public Health, vol. 17, no. 5, 2020, (https://doi. org/10.3390/ijerph17051729)

Werner, Emmy E. - Smith, Ruth S., Vulnerable but invincible: A longitudinal study of resilient children and youth, New York, McGraw-Hill, 1982.

World Health Organization, Statement on The Second Meeting of The International Health Regulations (2005) Emergency Committee Regarding the Outbreak of Novel Coronavirus (2019-Ncov), 30 January 2020, (https://www.who. $\mathrm{int} /$ news-room/detail/30-01-2020-statement-on-the-second-meeting-of-the-in- 
ternational-health-regulations-(2005)-emergency-committee-regarding-the-outbreak-of-novel-coronavirus-(2019-Nov)

Xiao, Chunfeng, “A Novel Approach of Consultation On 2019 Novel Coronavirus (COVID-19)-Related Psychological and Mental Problems: Structured Letter Therapy", Psychiatry Investigation, vol. 17, no. 2, 2020, (doi: https://dx. doi.org/10.30773\%2Fpi.2020.0047)

Zheng, Wei, "Mental Health and A Novel Coronavirus (2019-Ncov) in China", Journal of Affective Disorders, vol. 269, 2020, (doi: https://dx.doi. org/10.1016\%2Fj.jad.2020.03.041) 